\title{
" Miraculous or Mired? Contrasting Japanese and American Perspectives on Japan's Current Economic Problems"
}

Simon Reich

CSG R Working Paper No. 21/ 98

D ecember 1998
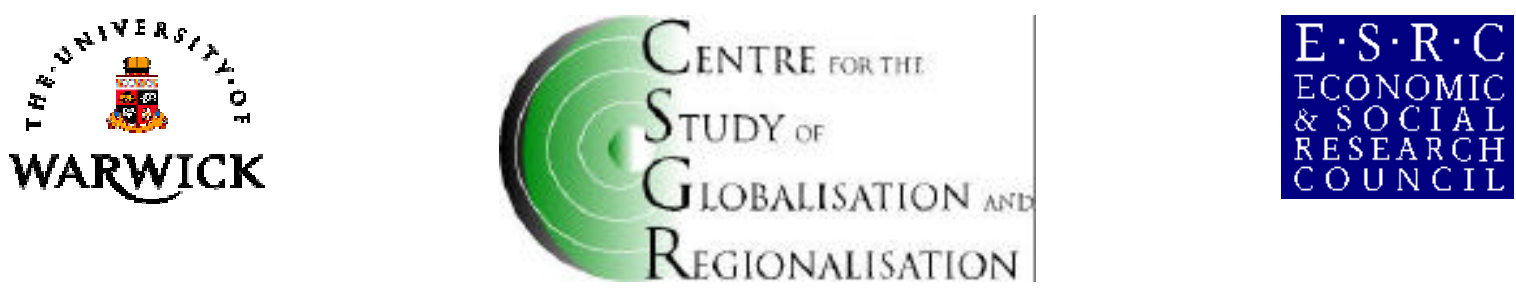

Centre for the Study of G lobalisation and Regionalisation (CSG R), University of Warwick, Coventry CV4 7AL, United-Kingdom. URL: http://www.warwick.ac.uk/fac/soc/CSGR 


\title{
Miraculous or Mired? Contrasting Japanese and American Perspectives on Japan's Current Economic Problems \\ Simon Reich \\ University of Pittsburg \\ CSG R Working Paper No. 21/ 98 \\ December 1998
}

\begin{abstract}
:
The current banking crisis in Japan illustrates two major points. The first is the renewed emphasis on the importance of market-based solutions to policy problems by American policy makers. The second is the broader point, that differences in the structures and operation of capitalism persist in the two countries despite the purported homogenising influences of globalisation. These two points are both analyzed in this paper through a systematic examination of the varied and contrasting positions in both Japan and the United States among policy makers and commentators regarding what kind of policies Japan should institute and the prospective success of such proposals. The paper offers a pessimistic conclusion that the most appropriate policy prescription requires bilateral policy coordination, a option that the United States has so far rejected and seems unlikely to initiate at this point.
\end{abstract}

Keywords: Globalisation, Banking crisis, Comparative Capitalism.

Address for correspondence:

Simon Reich

University of Pittsburgh

Pittsburgh

Pennsylvania 15260

USA 
"Japan is hostage to American prosperity, and America is hostage to Japanese frugality. Ethno-economics has locked the two nations in a loveless embrace, and smaller Asian economies into a sumo wrestler's hug by Japan. Something has to give. But what?"

\section{Murray Sayle}

'The Social Contradictions of Japanese Capitalism' The Atlantic Monthly, June 1998, page 94.

\section{Introduction}

.It was only a handful of years ago that the World Bank referred to the East Asian economic miracle in glowing terms. The Bank then noted that the "rapid growth in each economy was primarily due to the application of a set of common, market-friendly economic policies, leading to both higher accumulation and better allocation of resources...........The importance of good macroeconomic management and broadly based educational systems for East Asia's rapid growth is abundantly demonstrated". ${ }^{1}$ Even The Economist then noted that these countries "got the economic fundamentals right, with low inflation, sound fiscal policies, high levels of domestic saving, heavy investment in education; and they kept their economies more open to foreign technology than most other developing countries."2

Today, five years later, the foundation upon on which that mixture of capitalism and democracy rests has been pilloried by Anglo-American observers, politicians and officials from international financial institutions (IFIs) like the IMF alike. Yet East Asians have been reluctant to accept the prescriptions proffered by their Western counterparts, often responding that their economies have more vitality than these counterparts concede, even in the face of growing financial crises. ${ }^{3}$

Many Japanese leaders, in particular, see their current problems as cyclical, and subject to effective response through an incremental policy approach, rather than basic internal wholesale structural change. They consider the source of their problems to be relatively

\footnotetext{
${ }^{1}$ See comments by Lewis T. Preston, then President of the World Bank, in The East Asian Miracle: Economic Growth and Public Policy (Washington DC: International Bank for Reconstruction and Development, 1993), p.VI.

${ }^{2}$ See 'Economic Miracle or Myth?', The Economist, 2 October 1993, p.41.

${ }^{3}$ See, for example, comments in David E. Sanger, 'Clinton's Personal Touch in Asian Rescue', New York Times, 18 December 1997, p. C8.
} 
innocuous, based on cyclical macro-economic trends. ${ }^{4}$ Anglo-American critics argue, in contrast, that fundamental shifts in the nature of democracy and the structure of capitalism, not incremental policy adjustments, are required throughout most of East Asia, including Japan. ${ }^{5}$

Within the last decade, Japan has therefore fundamentally shifted in the perceptions of Americans. It was formerly considered a rival capitalist model to the Anglo-American variant in East Asia and an effective long-term threat to the vitality of the American economy. A decade later it is now considered in desperate straits and in need of massive reform, in order to avoid both its own implosion and inflicting enormous damage on both the U.S. and the region's economy. The Economist succinctly articulated the dominant American view about Japan's regional influence when it suggested that:

Japan's plight has not caused the region's ills. But it affects Asia in two ways. Lack of demand in its economy - much the region's biggest - means that the crippled tigers cannot export their way to recovery. Sales to Japan account for as much as $12 \%$ of Malaysia's GDP, and 5-7\% of GDP in Indonesia, Thailand, South Korea and Taiwan. In addition, the weak yen reduces the competitive advantage that the Asian devaluations would

\footnotetext{
${ }^{4}$ Such a view contrasts with that of other East Asian leaders. Most explicit on this point have been Mahathir and Suharto (the latter in a speech marking his departure from office) who both suggested that the various East Asian financial crises are not the product of cyclical economic factors but of purposive western behaviour designed to subordinate Asian modes of capitalism. See, as examples, Mahathir's comments cited in David E. Sanger, 'Bashing America for Fun and Profit', New York Times, 5 October 1997, Section 4, p.1; Thomas L. Friedman's discussion of Mahathir's response to the East Asian economic crises in his article entitled 'Mahathir's Wrath', New York Times, 18 December 1997, p.A27; or Nicholas D. Kristof, 'Suharto's Stealthy Foe: Globalizing Capitalism', New York Times, 20 May 1998, P.A8.

${ }^{5}$ Again, just one example is provided by Martin Lee in suggesting that the Asian economies who have weathered the economic crises in the region best are those who reject "Asian values' of "authoritarianism" and "strong government" and corruption in favour of "Western concepts" of democracy and human rights. According to Lee, both political and economic reforms have been carried out among the region's smaller countries that have faired better, such as Taiwan and the Philippines. See Martin Lee, 'Testing Asian Values', The New York Times, January 18, 1998, p.17. A comparable argument against Asian capitalism, with its apparent focus on cronyism, is made by Kristof, op. cit. Asians, in contrast, argue that the IMF understands nothing about such embedded regional principles as familialism. See Seth Mydans, 'Suharto Faults IMF on Family Principle', New York Times, 9 March 1998, p.A8. But a notable caveat is in order in recognising Linda Weiss' point that there is not one single model of development followed by all Asian countries but distinctions between Japan and South Korea and the rest of (particularly Southeast) Asia where the state has not played as central a role. See Linda Weiss, The Myth of the Powerless State (Ithaca, NY: Cornell, 1997).
} 
otherwise have given the tigers' currencies. On the face of it, Asia needs both stronger demand in Japan and a stronger yen. ${ }^{6}$

This paper seeks to explain why and how Americans have changed their views, what distinguishes the dominant American and Japanese perspectives, and what the implication of stark contrasts in Japanese and American perspectives is for the prospect of consolidated and effective economic policy co-ordination in the region.

I argue in this paper that Americans have oscillated in the second half of the Twentieth Century between two conflicting positions. The first is an acceptance of the fact that Japan operates a distinct form of capitalist democracy; the second is an insistence that the forms of capitalist democracy practised in the two countries converge (if only generally towards the American variant of liberal democracy). We are, I contend, currently witnessing a period of American evangelical push towards a convergence hypothesis that is reflected in both the substance and the instruments of U.S. policy towards Japan. Much of this change of attitude, I suggest, has been stimulated by the same propensities that dated from the early 1980s, as America pursued a neo-liberal agenda in the aftermath of the election of Ronald Reagan. The same ideological proclivities that successfully battled against Communism are now evident in the challenge mounted against contending forms of capitalist democracy. ${ }^{7}$ The central component of the argument I offer in this paper is that the triumphal component of U.S. foreign policy has now evolved beyond its Cold War dimension to a second round that confronts alternative forms of capitalism. In this instant it is the East Asian variant that it epitomised by Japan, the largest and currently most important of Asia's economies.

In contrast to their Soviet counterparts, however, the Japanese are more likely to resist these efforts effectively. Mainstream Japanese thinking fundamentally disagrees with the Americans in their basic assumptions over the source, intensity and current state of the

\footnotetext{
6 ‘As Japan goes?', The Economist, 20 June 1998, p.17.

${ }^{7}$ For a discussion of the contribution of the Reagan and Thatcher Administration's in promoting a neo-liberal agenda see Robert Solomon, The Transformation of the World Economy, 1980-1993 (London: MacMillan, 1994).
} 
Japan's economic difficulties -- and what appropriate corresponding policy proposals they therefore advocate.

Given the likelihood of Japanese resistance to massive reform, the need for a suitable regional institutional mechanism designed to co-ordinate bilateral (and multilateral) policy solutions is evident. But no such effective body currently exists. Despite the presence of APEC, the prospect of an institution emerging to co-ordinate policy and mitigate the region's current problems is not good. With the likelihood of massive reform in Japan slim, and the prospects for policy-co-ordination dim, it is unlikely that concerted, co-ordinated and choreographed U.S.-Japanese action will successfully provide relief for the region's other economies. Indeed, pallid recent joint efforts to halt the decline of the yen by the U.S. Treasury and the Bank of Japan provided nothing more than a temporary panacea for a longterm problem and revealed the limits of current policy co-ordination between the two countries. $^{8}$

By any objective measure, a desire for any form of corrective action in Japan is most compelling for two reasons: First, Japan has been a more significant model for economic development in East Asia than is often assumed. Any effective solution there is likely to assist other countries in the region in thinking about appropriate policies. Second, Japan's economic welfare - its influence on the trading and financial system -- has an enormous impact on the other economies of the region. Simply stated, they are heavily dependent on developments in Japan. ${ }^{9}$ Thus, without American and Japanese bilateral co-operation, the likelihood of the region's troubled economies reviving is limited. The implications of

\footnotetext{
${ }^{8}$ See Ronald McKinnon and Keneichi Ohno, 'The Real Yen Worry', The Financial Times, 26 June 1998, p. 14.

${ }^{9}$ For the issue of Japan's role as a model in Asia see Walter Hatch and Kuzo Yamamura, Asia in Japan's Embrace: Building a Regional production Alliance (Cambridge: Cambridge University Press, 1996); Linda Weiss, The Myth of the Powerless State (Ithaca, NY: Cornell University Press, 1997). According to Stephen Roach, "Asian countries other than Japan account for just 7 percent of global trade - or just 1.5 percent of the world's gross domestic product." See Stephen S. Roach, 'Asia may pinch us yet', New York Times, 24 February 1998. According to World Development Report figures, Japan's GDP accounted for approximately 73 percent of the East Asia's total GDP (excluding Taiwan) in 1995. See The State in a Changing World: World Development Report 1997 (NY: International Bank for Reconstruction and Development for the World Bank, 1997), Figures taken from Table 12, p.236. Obviously, the inclusion of figures for Taiwan and the PRC's growth in the last three years would reduce that percentage. But the GDP figures, coupled with Japan's major direct investments in the region, still make it abundantly clear that Japan's welfare has a enormous impact on the health of East Asia's economy. For a comprehensive American popular perspective of the state of Japan's economy see Brian Bremner, 'Japan’s Real Crisis', BusinessWeek, 18 May 1998, pp.136-142.
} 
ineffective or zero joint action cannot be overstated. As Henry Sender recently commented in the Far Eastern Economic Review,

Washington's refusal to help the Japanese sort out the mess in their economy and financial systems is bad news for Asia. It means that Asia is hostage to a tug-of-war between a Japanese government that is seemingly paralysed and an American government that seems ever more frustrated with that paralysis. Since the Plaza Accord, Japan had been a locomotive for Asian growth; when it runs out of steam as it has so dramatically in recent weeks-so too do Asian economies. ${ }^{10}$

Sender is plausible in arguing that Japanese-U.S. bilateral policy co-ordination is key to an Asian recovery, particularly if it is designed to stabilise the value of the yen. While the perils of East Asia's economies have been extensively chronicled in the American press, it is that of the Japanese economy that is of greatest concern to the regional, and indeed global, economy.

Yet, there exists an apparent, consistent and startling contrast in the perspectives (and policies) of Japanese and American decision-makers in relations to Japan's present plight. This difference raises a series of related questions about the prospects for policy coordination and Japan's renewed economic robustness. They express sharply divided views concerning the underlying strength of the Japanese economy and the most appropriate measures for reform

All sides simultaneously acknowledge that certain aspects of Japan's economy -- like its export surplus -- continues to operate in a highly effective fashion. ${ }^{11}$ Yet they do seem to coalesce on the issue of policy prescriptions; the majority of American commentators believing that major reform is required in Japan while the majority of Japanese counterparts appear to dissent from this view. Certainly, they appear to contrast in their estimation of the utility of current Japanese policy, notably the consequence of these export activities for the region's vitality. U.S. critics contend that robust Japanese exports represent a temporary panacea that will only result in a 'competitive currency devaluation' race rather than to cure

\footnotetext{
${ }^{10}$ Henry Sender, 'A New Wave of Pain', Far Eastern Economic Review, 25 June 1998, p.62.
} 
the structural problems they see as endemic to many of the national economies of the region. $^{12}$

Senior American officials, such as Deputy Treasury Secretary Lawrence Summers, contend that growing Japanese export surpluses will threaten the region's other economies by displacing those countries' products in third markets. ${ }^{13}$ Such surpluses, he believes, will therefore enhance the prospect for a 'race to the bottom' in a damaging deflationary environment, with a serious risk that the Peoples' Republic of China will be dragged into the crisis by deciding it has to devalue its currency. ${ }^{14}$ How realistic is this threat? Well, despite contrary statements by other PRC governmental officials, one senior Chinese central bank official warned that the "pressure for devaluation will increase in the second half of 1998 due to the impact of the financial crisis on China's exports". ${ }^{15}$

The Japanese response is that enhancing exports is one major instrument in ending the crisis. Consistent with traditional policy, a weakened yen will enhance this capacity and 'jump start' the Japanese economy with the assistance of a macro-economic policy of government spending and tax cuts designed to enhance domestic demand. American's are bewildered by this response. They consider this much of the same kind of policy response that has worked so ineffectively before and push the Japanese to offer a radical solution. American frustration with Japan's policy utterances is reflected in the truncated response of one American journalist who recently uttered, "If Japan would only listen........."16

\footnotetext{
${ }^{11}$ See Janet Bush and Robert Whymant, 'Markets Slump as Asia Crisis Bites', The Times, 13 June 1998, p.27.

${ }^{12}$ See, for example, Simon Kuper, 'Currencies: Everyone wants a strong dollar', 19 September 1997, Financial Times.

${ }^{13}$ See Lawrence Summers quoted in 'Deputy Treasury Secretary Summers Warns Growing Asian Financial Crisis Could Effect Crucial Security Interests in Region and Impact U.S. Savings', http://biz.yahoo.com/bw/980708/asian_fina_1.html.

${ }^{14}$ See for example, the comments in a Financial Times Report, 'US Exports: Asian Crisis Starts to Take Toll', Friday June $19^{\text {th }} 1998$; James Kynge and John Ridding, 'Asian Crisis: China calls for Japan to act', Financial Times, June 10 1998; Seth Faison, 'Chinese Economic Leaders Read a Warning in Asian Crisis', New York Times, 15 January 1998, p.C26.

${ }^{15}$ See quote in report by Zhanglin Lin and De An Yin, 'China Reaffirming 'No-Devaluation' vow amid mounting worries', Monday May 11 1998, China News Digest, Global News no. GL98-065,

${ }^{16}$ Brian Bremner, 'Japan's Real Crisis', Businessweek, 18 May 1998, p.136.
} 
What one side (the Japanese) sees as an instrument of repair, the other (the Americans) therefore paradoxically considers to be emblematic of a deepening of crisis, with strong export figures providing foreign critics with what they interpret as evidence of continued sluggish domestic demand and the need for deregulation. ${ }^{17}$ This basic disagreement in the appropriate instruments and reading of indicators is just another layer in the multitude of contentions and confusion that does not augur well for regional policy co-ordination.

This paper outlines these and other bases of disagreement in understanding the current economic crisis in Japan. Furthermore, it considers the consequences of the varied American and Japanese interpretations of events in Asia in general, and Japan in particular, for policy co-ordination. In addressing these issues, I initially provide a context against which to assess differing Japanese and American interpretations (which conflict both within and across borders). Essentially, I argue that current understandings of Japan's problems, and corresponding assessments of both their implications and policy prescriptions, are founded upon contrasting definitions of capitalism and democracy -- distinctions long suppressed by the exigencies of the Cold War but that have re-emerged in its aftermath.

During the Cold War historic American efforts to stimulate convergence in political and economic structures in the conquered Axis powers were abandoned (in Japan) or curtailed (in a divided Germany) because of the primacy accorded to security considerations. In the 1990s, however, Communism neither offers a viable organisational and intellectual alternative or a realistic security threat. In the absence of a unifying enemy -- and with globalisation offering centrifugal external pressures - contrasting practitioners of capitalism and democracy have three options. The first is to converge to the hegemony of one system. A second is to compromise and find one common way to practice democracy and to structure capitalism in a manner that integrates aspects of different kinds of systems. A third is to learn how to develop mechanisms that can arbitrate the differences. The current process, I contend, is a critical test of these alternatives - conquest, harmonisation or mutual recognition. The purpose of policy co-ordination is to avoid the latter and ensure that economic conflict, does not ensue. The current American propensity pushes Japan towards a particular type of radical

\footnotetext{
${ }^{17}$ This point is illustrated in an article by Gillian Tett entitled 'Japan: Damper on Celebrations', Financial
} 
reform (without providing effective assistance to do so even if that's what the Japanese wanted) or to face the prospect of being mired as a consequence. The current Japanese response is to resist American impulses and insist that the problem can be addressed within the context of traditional policy responses. The possibility that, in fact, the magnitude of Japan's problems involves co-ordinated policy suggests, if correct, an intractable problem in this context that may ultimately do damage to both national economies, as well as the global economy.

Thus, the section that follows outlines the thrust of American foreign policy thinking in the 1990s. It delineates the influential ideological components of the American variant of globalisation. The ensuing section then examines varied Japanese and American perspectives on the sources of, and prescriptions for, Japan's current problems. A final section will consider the implications of each country's dominant perspective for the prospects of policy co-ordination.

\section{Neo-liberalism Triumphant: The Changing Contours of American foreign policy in the 1990s}

The end of the Cold War signified, for many in the West, an ideological triumph of democracy and capitalism. ${ }^{18}$ According to this view, the fall of the Berlin Wall was to presage a period of peaceful convergence, with the prospect of prosperity and reduced friction. Francis Fukuyama suggests that convergence is inevitable and largely nonconfrontational:

Technology makes possible the limitless accumulation of wealth, and thus the satisfaction of an ever-expanding set of human desires. This process guarantees an increasing homogenisation of all human societies, regardless of their historical origins or cultural inheritances. All countries undergoing economic modernisation must increasing resemble one another: they must unify nationally on the basis of a centralised state, urbanise, replace

\footnotetext{
Times, 19 September 1998.

${ }^{18}$ As good examples see (in the short form) Mortimer Zuckerman, 'A Second American Century', Foreign Affairs, Vol. 7, No. 3, pp.18-31; and (for a longer form) see Robert Solomon, The Transformation of the World Economy, 1980-1993 (London: MacMillan, 1994), especially p.7.
} 
traditional forms of social organisation like tribe, sect, and family with economically rational ones based on function and efficiency, and provide for the universal education of their citizens....Moreover, the logic of modern natural science would seem to dictate a universal evolution in the direction of capitalism..... The social changes that accompany advanced industrialisation, in particular universal education, appear to liberate a certain demand for recognition that did not exist among poorer and less educated people. As standards of living increase, as populations become more cosmopolitan and better educated, and as society as a whole achieves a greater equality of condition, people begin to demand not simply more wealth but recognition of their status. ${ }^{19}$

The liberal peace argument is consistent with - and a corollary of -- this broad convergence thesis. Simply stated, proponents of this view claim that democracies don't start wars with other democracies. Advocates of this thesis were soon in full throttle, their claims being debated and ultimately gaining widespread acceptance in both the hallways of Washington and amongst some of America's pre-eminent scholars. ${ }^{20}$ Yet the embrace of the concept of the 'New World Order' signalled a false start in the construction of a new foundation for both the international system and American foreign policy.

John Mearsheimer's suggestion that we'd all 'soon miss the Cold War' may have been an overstatement. But conflict has, in fact, intensified in some senses and certainly taken on a

\footnotetext{
${ }^{19}$ Quotations taken from Francis Fukuyama, The End of History and the Last Man (NY: Free Press, 1992), pp. xiv-xv, and xviii-xix. Fukuyama's voice met with widespread approval in American policy circles, albeit largely an unreconstructed restatement of the central thesis of modernisation of Daniel Bell and Seymour Martin Lipset. This formulation had first emerged in the 1950s, emphasising an Anglo-Saxon version of modernity in which particularistic notions of capitalism and democracy are explicitly linked. This formulation was largely discredited by its lack of empirical substantiation and replaced in the 1970s by increasingly popular dependency and world systems theories, often originating from Latin America. See Daniel Bell, The End of Ideology: On the Exhaustion of Political Ideas (Glencoe, Ill: Free Press, 1960); See Seymour Martin Lipset, 'Some Social Requisites of Democracy: Economic Development and Political Legitimacy', American Political Science Review, March 1959, pp. 69-105; and the volumes of the Committee on Comparative Politics of the Social Science Research Council.

${ }^{20}$ Perhaps the most notable example is Michael Doyle, 'Liberalism and World Politics' in American Political Science Review, Vol. 80, no.4, December 1986, pp.1151-1169. For a collection of essays on this theme see Sean M. Lynn-Jones, and Steven E. Miller (eds.), Debating the Democratic Peace.
} 
different form in others. ${ }^{21}$ It is now more often organised around ethnic dimensions (whether in Bosnia, Kosovo, Rwanda or Indonesia) or in the form of a keener contest over the primary principles of democracy and the structure of capitalism than was the case during the Cold War. Indeed, the structure of capitalism and the advent of ethnic conflict are often related, as the persecution of the Chinese in Malaysia and Indonesia recently demonstrates. The substance of conflict now focuses on immigration and welfare, non-proliferation and drug interdiction, challenging the traditional paradigm about what constitutes a threat, the traditional substance of security debates, and traditional views concerning the appropriate instruments for addressing security concerns. ${ }^{22}$

The end of that same Cold War, nevertheless, ushered in a new sense of awareness and adventurism among American policy makers -- and a corresponding shift in potential policy options as the features of global markets began to alter radically. As Jeffrey Garten (who served for five years as a high ranking official on the U.S. Department of State's policy planning staff and later as U.S. Under-secretary for International Trade in the Department of Commerce) commented on Japan and Germany in 1992, "You might envy or resent them but you'll see these two nations in a mirror in which we can see our own weaknesses and strengths but mostly the weaknesses." What America needed, he concluded, was "a revolution in our thinking about where the world is headed and how we had better change our own priorities". 23

Yet little has changed in American thinking about either models of development or the agenda, location or instruments of policy co-ordination. Despite Garten's warning, it ushered in merely a greater sense of confidence among many in the U.S. policy community. After an

\footnotetext{
${ }^{21}$ This now famous comment comes from John Mearsheimer, 'Back to the Future: Instability in Europe after the Cold War', in Sean Lynn Jones (ed) The Cold War and After: Prospects for Peace, (Cambridge: MIT Press, 1991).

${ }^{22}$ For interesting examples of the new security agenda see H. Richard Friman, "Gaijinhanzai: Immigration and Drugs in Contemporary Japan" Asian Survey, 36, 10, 1996 pp. 964-78; Wayne Cornelius, Philip L. Martin, and James F. Hollifield, eds., Controlling Immigration: A Global Perspective. A more celebrated example is provided by Samuel Huntington, 'The Clash of Civilizations', Foreign Affairs, Summer, 1993, pp.22-49; Phil Williams, 'The Nature of Drug-Trafficking Networks, Current History, April 1998, pp.154-159.

${ }^{23}$ Jeffrey E. Garten, in A Cold Peace: America, Japan, Germany and the Struggle for Supremacy, (New York, Random House, 1992), p.4. See also Lester Thurow who offers, perhaps, a more detached analysis of the economic conflict among liberal democracies in Head to Head: The Coming Economic Battle Among Japan, Europe and America, (London: Nicholas Brealey, 1992).
} 
extended period of time in which American companies had come under intense pressure from East Asian and European competitors, new markets opened and major trade and investment opportunities appeared. No longer did American corporations struggle to adapt to a market environment that had, for over four decades, prized stability over flexibility, incrementalism over entrepreneurialism. As the borders of the world economy expanded in the 1990s to include an overwhelming percentage of the former Communist world, it is American companies who often (although neither exclusively nor uniformly) responded most aggressively. The character of global markets (albeit perhaps temporarily) has changed, from stable, predictable and driven by Fordist principles of mass production to volatile and consumed by principles of product customisation (or 'glocalisation', as it was initially termed by Akio Morita, the late chairman of Sony). ${ }^{24}$ And with these changes, proponents of globalisation began to speak of a convergence towards 'best practice', whether the term was applied functionally in the public sector in the way economic or political institutions operate or how corporations behave in contemporary markets in the private sector. ${ }^{25}$

Opposition, sometimes muted and other times ineffectual, has been slow to organise as the contours of action have often shifted from national forums to transnational ones, often leaving the Left disorganised and confused. ${ }^{26}$ American government officials spoke in triumphant terms of the new found primacy of "free markets, civil society and the rule of law" in "adding the PRC and Newly Independent States (of the former Soviet Union) to the global system and thus concluding a rehabilitation of that system that began with Japan and Germany in 1945 ". ${ }^{27}$

Emboldened by the defeat of Communism, Americans generally pursue policies that were designed to radical change the structure of the emerging markets of Central and Eastern

\footnotetext{
${ }^{24}$ For a discussion of the change in the pattern of world markets and the concept of 'glocalisation' see Winfried Ruigrok and Rob van Tulder, The Logic of International Restructuring (London: Routledge, 1995), especially pp. 9-10.

${ }^{25}$ For a critique see Paul N. Doremus, William W. Keller, Louis W. Pauly and Simon Reich, The Myth of the Global Corporation (NJ: Princeton, 1998).

${ }^{26}$ For a brief manifesto of both the normative values and political strategies of the mainstream political Left see 'Preface' to the special issue on 'Globalisation and the Politics of Resistance', by John Kenneth Galbraith, New Political Economy, Volume 2, number 1, March 1997, pp.5-10.
} 
Europe. Macroeconomic strategies advocated by notable American economists were predicated on comparable market-dominant policies that had so appalled Karl Polanyi in his study of England prior to, and during, the Industrial Revolution. ${ }^{28}$ Jeffrey Sachs, for example, advocated shock treatment for long-stymied economies as far apart as Poland and Peru. These measures were designed to reduce inflation, increase external demand, and -- if necessary as a consequence -- greatly increase unemployment while deliberately retrenching safety nets. ${ }^{29}$ The end product didn't appear to be all that different in substance from that described by Polanyi. Unemployment soared, social disruption intensified (often in the form of crime) and wealth concentrated as the gap between rich and poor became increasingly attenuated in many countries. ${ }^{30}$

IFIs have largely adopted the agenda of neo-classical economics as their own, with the cooperation of many states imbued with a complimentary neo-liberal post-war ideology. ${ }^{31}$ Policies predicated on monetarist principles that disown union representation have become increasingly popular in parts of the OECD and in some emerging economies, particularly Latin America. ${ }^{32}$ While there is little 'testable' data to support the proposition that a transnational alliance exists of the type articulated by Steven Gill, ${ }^{33}$ there is plenty of evidence that the resurgent intergovernmental organisations -- as well as the most notable of the emergent nongovernmental human rights organisations -- embrace Anglo-American values. This entails a politically liberal form of Lockean democracy and an economically liberal Smithian form of capitalism. In that limited sense, a 'historic bloc' may be under

\footnotetext{
${ }^{27}$ Comment by Charlene Barshefsky in a speech she gave on May 5 at a conference organised by the Economic Strategy Institute entitled 'Whither Globalism: A World in Crises?' held at the Hyatt Regency in Washington DC, on 5-6 May 1998.

${ }^{28}$ Karl Polanyi, The Great Transformation: The Political and Economic Origins of Our Time (Boston: Beacon Press, 1944).

${ }^{29}$ Jeffrey Sachs, 'Poland and Eastern Europe: What is to be Done?' in Andras Koves and Paul Marer, eds., Foreign Economic Liberalization: Transformations in Socialist and Market Economies (Boulder, Co: Westview Press, 1991). See also Bela Belassa, "Policy Choices in Newly Industrialising Countries' in the same volume. ${ }^{30}$ See Daniel Rodrik, Has International Economic Integration Gone Too Far? (Washington, Institute for International Economics, 1996); Marina Wes, Globalisation: Winners and Losers (London: IPPR, 1995).

${ }^{31} \mathrm{~A}$ few interesting examples of countervailing responses now exist. For an interesting discussion of the retreat of such reforms in Eastern Europe see Alice H. Amsden, Jacek Kochanowicz and Lance Taylor, The Market Meets its Match: Restructuring the Economies of Eastern Europe.

${ }^{32}$ For an exemplary recent analysis of the role of interventionist states in advancing the process of globalisation that mixes sophisticated theory and good empirical evidence in the case of Latin America see Nicola Phillips, Globalisation and State Power: Political and Economic Reform in Argentina, 1989-1995 (PhD thesis, LSE, University of London, 1998).

${ }^{33}$ Stephen Gill, American Hegemony and the Trilateral Commission (Cambridge: Cambridge University Press, 1990).
} 
construction that articulates what Gill refers to as a 'market civilisation'. ${ }^{44}$ Such comprehensive policy changes, among the larger and most economically advanced (and advantaged) states, and the largest IFIs and Non-Governmental Organisations (NGOs) have, collectively, effectively terminated the institutional and ideological construct termed by John Ruggie as 'embedded liberalism'. 35

Still, it is hard to credit all this change as 'hegemonic', even if a bloc is forming, because that may be granting it more strategic coherence then it deserves. Yet, from an Asian perspective, capitalist liberal democracy is being defined in increasingly restrictive contours. Miles Kahler has specified three options for arbitrating and negotiating the differences between capitalist systems --institutional competition (mutual recognition), managed trade (e.g. through quotas or export restraint agreements) and 'harmonisation' (in the sense of imposing standards). ${ }^{36} \mathrm{~A}$ fourth option is to suggest that the market mechanism might be responsible for arbitrating the difference between systems, simply by punishing those considered inefficient in classical neo-liberal terms. While the former two (institutional competition and managed trade) predominated as a system of reconciliation in the 1970s and 1980s -- with a proliferation of VERs, VRAs, quotas and tariffs on trade (often most notably between the largest countries of the OECD) -- that has not been the case in the 1990s. Harmonisation, creating the same pattern for all countries, has grown as the preferred option, whether in the form of universal EU rules after Maastricht or US demands for financial reform in Japan. This, and marketimposed reforms, seem to have replaced institutional competition and managed trade.

The neo-liberal agenda thus seems to have altered the balance, with governments purportedly playing a severely limited role confined to intervention in support of harmonisation, privatisation and deregulation. In contrast, markets, NGOs and IGOs have become

\footnotetext{
${ }^{34}$ The concept of the historic bloc was certain best articulated, if not indeed first coined, by Robert Cox in Production, Power and World Order: Social Forces in the Making of History (New York: Columbia University Press, 1987). Its usage has been applied to the concept of globalisation by Stephen Gill in 'Globalisation, Market Civilisation and Disciplinary Neo-Liberalism', Millennium, 24 (3) 1995, pp. 399-422.

${ }^{35}$ John G. Ruggie, 'At home abroad: international liberalisation and domestic stability in the new world economy', Millennium, 24, 1995 pp.507-26. See also John G. Ruggie, Winning the Peace: America and the World Order in the New Era, New York: Columbia University Press, 1996. For a substantiation of this view see Jeffrey A. Hart and Aseem Prakash, 'The Decline of 'Embedded Liberalism' and the Rearticulation of Keynesian State', New Political Economy, Vol. 2, No. 1, 1997, pp.65-79.

${ }^{36}$ Miles Kahler 'Trade and Domestic Differences' in Suzanne Berger and Ron Dore, (eds) National Diversity
} 
increasingly important as authority structures. ${ }^{37}$ American foreign policy makers suggest that they have responded to this change. Alternatively, as I suggest, they U.S. foreign policy be interpreted as having assisted in promoting the status of those same non-state actors.

\section{Abiding Ambivalence in US Strategies towards Japan.}

American policy makers and academics reflect this shift in preferences from institutional competition and managed trade to harmonisation and market reform. Over the last two decades, an assortment of 'revisionist' Americans have written in awe of the capabilities of the Japanese State and Japan's consequential economic achievements. This is a varied group, including scholars such as Chalmers Johnson, policy 'wonks' such as Clyde Prestowitz, as well as more populist journalists-turned-authors such as James Fallows. ${ }^{38}$ They all share a profound admiration for the way in which Japan has seemingly been run so effectively by the bureaucracy, the capabilities of the economy, and a belief (albeit to varying degrees) that the activities of Japanese firms are both understandable and potentially predatory to the interests of the U.S. economy. Their conclusion is therefore that the Japanese system is different, but often their prescription is that 'we should be more like them' rather than, as many often mistakenly claim, that the Japanese should be 'more like us' ${ }^{39}$

Opposed by liberal economists such as Gary Hufbauer because of the influence these authors consistently credit to bureaucrats in Japan for its economic miracle, ${ }^{40}$ these revisionists have

\footnotetext{
and Global Capitalism (Ithaca: Cornell University Press, 1996), especially p.300.

${ }^{37}$ For a discussion of this point see Jessica Tuchman Matthews, 'Powershift', Foreign Affairs, Vol. 76, No. 1, pp.50-66; see the response by Anne-Marie Slaughter, "The Real New World Order", Foreign Affairs, September/October 1997.

${ }^{38}$ For examples see Chalmers Johnson, MITI and the Japanese Miracle: The Growth of Industrial Policy, 19251975 (Stanford: Stanford University Press, 1982); Clyde Prestowitz, Trading places: how we are giving our future to Japan and how to reclaim it (New York: Basic Books, 1989); James Fallows Looking at the Sun: The

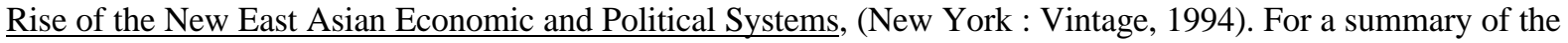
debate between those who focus on the role of the bureaucracy and those who stress market-based factors in accounting for Japan's competitiveness see Greg Noble, 'The Japanese Industrial Policy Debate,' in Stephan Haggard and Chung-in Moon, eds., Pacific Dynamics: The International Politics of Industrial Change, (Boulder, Col: Westview, 1989), pp. 53-95.

${ }^{39}$ Perhaps the most explicit and resolute statement of this view is offered by Chalmers Johnson in a approving review of James Fallows' book, Looking at the Sun. See Chalmers Johnson, 'Intellectual Warfare', Atlantic Monthly, January 1995, pp.99-103.

${ }^{40}$ See, for example, Gary Hufbauer and Kimberly Ann Elliott, Measuring the Costs of Protection in the United States (Washington, D.C.: Institute for International Economics, 1994). Edward Lincoln offers a more moderated position in which an economist does support the notion of significant bureaucratic influence in Japan's Unequal Trade ( Washington, DC: Brookings Institution, 1990).
} 
traditionally focused on the 'politics of productivity' that gave primacy to manufacturers rather than consumer interests. Such an approach included an export orientation in goods and services, and a stable financial structure in which cross-shareholding predominated, debt was cheap, and full employment, research and development were regarded as sacrosanct. ${ }^{41}$

American policymakers clearly recognise the growth of Japan's economy and the challenge it poses to the welfare of the American economy. Although perhaps over-elaborated and dated in the late 1990s (in view of Japan's credit crunch), Jeffrey Garten's statement does make that point emphatically:

Japan, whose economy is about the combined size of West Germany, Britain and France, has become the world's primary banker, the source of most new lending and investing across borders...........In recent years it has outpaced all other industrial countries in its economic growth, savings rate, and volume of new investment. Form automobiles to flat panel computer screens, Japanese companies are moving to dominate a number of the world's most important technologically intensive industries. Not only are Japanese firms becoming models for multinational companies' production strategy and managerial style, but they are the central driving force behind a borderless, technologically-driven world economy. Moreover, Tokyo is the dominant economic power in the most dynamic region of the world - the corridor from Seoul to Sydney, encompassing Hong Kong, Singapore, Taiwan, Thailand, Malaysia, and Indonesia". ${ }^{4}$

When choosing a strategy in economic and social policy towards Japan, the U.S. has historically demonstrated great ambivalence. Post-war attempts at the types of comprehensive reforms carried out in Germany were abandoned in the face of the exigencies of the Korean War. ${ }^{43}$ Subsequent policies in trade negotiations, for example, have reflected a continuing

\footnotetext{
${ }^{41}$ For a recent summary of this argument see Linda Weiss, The Myth of the Powerless State (Ithaca, NY: Cornell, 1997).

${ }^{42}$ Garten, op. cit. P.9.

${ }^{43}$ See Leon Hollerman, "International Economic Controls in Occupied Japan." Journal of Asian Studies, 38, 4 (August 1979), pp. 707-719; Hideichiro Nakamura, "Japan, Incorporated and Post-war Economic Growth." Japanese Economic Studies, 10, 3 (Spring 1982), pp. 68-109; Kozo Yamamura, Economic Power in Post-war Japan: Growth Versus Economic Democracy (Berkeley: University of California Press, 1967).
} 
conflict between a messianic idealism and a Realpolitik. Indeed, the two are pursued simultaneously to the consternation and confusion of the Japanese.

Of these two options, the proclivity of current U.S. foreign policy is predominantly towards a messianic posture, as discussed earlier in the introduction. It defies a pluralistic logic by rigidly arguing that democracy focuses on individual liberty of a Lockean nature (rather than, for example, Rousseau) and that capitalism is neoliberal in character, with the markets sovereign and regulation limited on the grounds that it is subversive. ${ }^{44}$ The capacity of the economy to generate collective goods through market structures is often reified as the product of the 'invisible hand', such goods being the accumulated total of individual action and the enforcement of market rules. ${ }^{45}$

Few would contend that fundamental differences exist in the ways in which the Japanese and American economies operate. ${ }^{46}$ The messianic thrust in US-Japanese relations is manifest in current American pressure for the Japanese to be 'just like us' ${ }^{47}$ In narrow operational economic terms, this means that corporate trading and distribution practices or systems of governance should be fundamentally altered so that they are not only compatible with, but indeed assimilate, the structure of American-style capitalism. The "one true form" approach implies that efficiencies are only attainable in seamless global markets, and that authority rests with the market mechanism while the state is simply intrusive unless it is simply

\footnotetext{
${ }^{44}$ Popularised versions of this distinction between contrasting forms of capitalism and polity are offered by James Fallows in 3 articles published in Atlantic Monthly, in November and December of 1993, and January of 1994 respectively entitled 'Looking at the Sun', 'How the World Works', and 'What is An Economy For?'

${ }^{45}$ For a macro-historical treatment of this argument in an institutional form see Douglas C. North and Robert P. Thomas: The Rise of the Western World: A New Economic History, (Cambridge: Cambridge University Press, 1973).

${ }^{46}$ As a reaffirmation of this point, see two pieces, one by Peter Gourevitch, After the Cold War in the Pacific Region: Uncertainties and Prospects' and the other by Peter Cowhey, 'Pacific Trade Relations After the Cold War: GATT, NAFTA, ASEAN and APEC' both in Peter Gourevitch, Takashi Inoguchi, and Courtney Purrington (ed.), United States-Japan Relations and International Institutions After the Cold War (La Jolla: Graduate School of International Relations and Pacific Studies, 1995).

${ }^{47}$ This is an admittedly vague, normative term. Its meaning is discussed more extensively in a broader political sense by Yumiko Mikanagi. She contends that, in political terms, it means citizen participation and pluralism to Americans. See Yumiko Mikanagi, Japan's Trade Policy: Action and Reaction? (London: Routledge, 1996), pp.7-9.
} 
assisting in that process. ${ }^{48}$ Kenichi Ohmae, for example, sees the nation state as '...an unnatural, even dysfunctional unit for organising human activity'. ${ }^{49}$

In this type of argument, the effects of globalisation through technological innovation curtails state influence. Glenn Fong, for example, has recently argued in this vein that the Japanese bureaucracy was formerly influential in the formulation and implementation of high technology policies. But the exigencies of the increased sophistication of technology (and of the projects themselves), coupled with changes in the international competitive environment, account for "a secular decline in the government's interventionist capabilities". As Fong suggests, "High level officials now have greater difficulty keeping tabs on technology, and have ceded initiative to a more dispersed set of players in closer touch with technological developments. As natural as this development might appear, such findings are important correctives to existing interpretations of the Japanese State and political economy". 50

Fong's thesis, however, is that convergence is inevitable (albeit, that he is clear in his argument that assimilation is driven by external forces and only under particular conditions). The evident effects of globalisation, whether through technological innovation or market liberalisation, has curtailed the power of states. ${ }^{51}$ Whether in bilateral, regional or multilateral forums, this argument challenges the assumptions that systems are fundamentally different. Either these differences have to be 'worked around' or one of the two systems have to be changed to ensure that commerce in not restrained.

\footnotetext{
${ }^{48}$ Perhaps ironically, one of the most vocal proponents of this approach is a Kenichi Ohmae, a co-opted Japanese citizen who works for over two decades for McKinsey, an American consultancy firm that personifies the values articulated. See Kenichi Ohmae, The Borderless World (New York, Fontana, 1990) and The End of the Nation State: The Rise of Regional Economies (New York: The Free Press, 1995). Popularisers of this approach include Lowell Bryan and Diana Farrell in Market Unbound: Unleashing Global Capitalism (NY: John Wiley, 1996); Henry Wendt, Global Embrace: Corporate Challenges in A Transnational World (NY: Harper Business, 1993).

${ }^{49}$ Kenichi Ohmae, The Evolving Global Economy: Making Sense of the New World Order (Boston: Harvard Business Press, 1995), p. 78.

${ }^{50}$ Quotations taken from Glenn R. Fong, 'Follower at the Frontier: International Competition and Japanese Industrial Policy", International Studies Quarterly, (1998) 42, pp.339 and 351.

${ }^{51}$ A broader version of this argument about the effects of technology on state power is offered by Susan Strange in her forthcoming book, Mad Money: A Sequel to Casino Capitalism (Manchester: University of Manchester Press, forthcoming 1998).
} 
Americans have often divided about how to respond to Japan. Should they demand the Japanese change the structure of their system (generally through liberalisation strategies) or simply accept that it is different and then pursue narrow self-interested policies by invoking measures designed to restrain Japanese exports and enlarge US market share in Japan? Evidence suggests that American policy makers have often been unclear about which they prefer but that two competing strategies have emerged.

Strategy 1. The 'Just like us' approach: harmonisation and market mechanisms. Perhaps the best example of the implementation of a 'just like us' policy in American economic strategies towards Japan was to be found in the Structural Impediments Initiative (SII) talks of the 1980s. ${ }^{52}$ Here American negotiators attempted to appeal to Japanese consumers over the heads of the government bureaucrats by pursuing an agenda that was aimed at Americanstyle, consumer-oriented changes. There were five components to the negotiations including demands for the institution of a macro-economic stimulus package through enhanced public spending and a reduction in real estate prices. The central aim of American policy was, however, to dismantle (preferably) or to curtail (minimally) the influence of the domestic keiretsu on the distribution system as barrier to trade. These 'enterprise groups' are "widely diversified, horizontally organised (or intermarket) corporate alliances at the upper reaches of the industrial chain". They are "networks built upon relationships of trust, the reciprocal exchange of information, technology and even management, and the expectations of longterm endurance. Within a corporate network, managers often compete energetically. But they also co-operate to the fullest extent required to maintain the network. During periods of crisis, this can entail directly intervening in one another's most intimate affairs". 53

American negotiators in the bilateral SII negotiations argued that these keiretsu operate individually as monopsonies over suppliers and collectively as an oligopoly over consumers, and that the effect of such a system is to restrict the access of foreign (American) goods and to raise prices for Japanese consumers. Evidence gives credence to such claims. One study suggests that keiretsu members are, on average, three times more likely to trade with an affiliate from the same kereitsu than with other firms. Such data supports the suggestion that

\footnotetext{
${ }^{52}$ See Leonard Schoppa Jnr., Bargaining With Japan: What American Pressure Can and Cannot Do (NY: Columbia Press, 1997).
} 
this is a form of alliance capitalism in which producers benefit at the cost to consumers - a sacrilegious act according to the American variant of capitalism. ${ }^{54}$ American demands for changes in the role of the keiretsu and in the distribution system (under the Large Store Law), which they then suggested was a related obstacle to the penetration of Japanese markets by foreign goods, was made with none or nominal effect. ${ }^{55}$

This strategy of trying to make Japan 'just like us' was also evident in sectoral negotiations such as between the two governments over the way in which bidding for contracts was structured in the case of major construction projects. Here, the U.S. pushed Japan to change its bidding system from 'designated bidder' to the 'open bidder' system employed in the United States. Although American negotiators did not achieve their primary goal, they did initially get the Japanese to agree to introduce a series of measures that allowed for greater transparency in the Japanese bidder system and, later, the Japanese announced that they would move towards an open bidder system. ${ }^{56}$

American government officials and industrialists at a micro-level have also recently echoed the same theme -- in this case regarding Kodak's case against Fuji brought before the World Trading Organisation (WTO). Kodak has consistently claimed that it is precluded from competing against Fuji by the influence exerted by Fuji and other keiretsu members on Japanese distributors of photographic film. Resonating a consistent theme, Kodak officials claim that Japanese consumers end up paying higher prices for (what they suggest is) an inferior product.

\footnotetext{
${ }^{53}$ Quotations taken from Paul N. Doremus, William W. Keller, Louis W. Pauly and Simon Reich, The Myth of the Global Corporation (Princeton: Princeton University Press, 1998), pp. 43 and 45.

${ }^{54}$ See Michael Gerlach, Alliance Capitalism: The Social Organisation of Japanese Business (Berkeley: University of California Press, 1992), p.265; See also James R. Lincoln, Michael L. Gerlach and Peggy

Takahashi, 'Keiretsu networks in the Japanese Economy: A Dyad Analysis of Intercorporate Ties', $\underline{\text { American }}$ Sociological Review, vol. 57, no. 5 (1992), pp.561-585.

55 Schoppa, op. cit., pp.86-94.

56 See Ellis S. Krauss, 'U.S. - Japan Negotiations on Construction and Semiconductors (1985-1988): Building Friction and Relation-chips. In Peter Evans, Harold K. Jacobson, and Robert D. Putnam (ed.), Double-Edged Diplomacy: International Bargaining and Domestic Politics, (Berkeley: University of California Press.1993).
} 
Strategy 2. The 'Different Capitalism' approach: Managed trade and institutional competition. As previously mentioned, an alternative American approach employed has often taken the form of recognising that differences persist in the way that the systems of capitalism operate, and that American demands should make allowances for these differences. The primary instruments used under those circumstances become that of managed trade.

There certainly is legitimate debate over whether American officials do, in fact, accurately understand the mechanics of the Japanese economy. But there undoubtedly are examples of episodes where American negotiators demand that Japanese government officials 'deliver' in the form of guaranteeing a share of the domestic market for US producers.

For Japanese government officials, the 1986 Semiconductor Agreement provides the formative, and still most important example of behaviour consistent with the principle that different forms of capitalism operate. Managed trade, in effect, here amounts to demand a guaranteed share of the domestic market rather than a complete revision of the way in which that market operates. ${ }^{57}$

By the early 1980s, Japanese semiconductor firms had surpassed United States-based firms in world market share for DRAMs, had become competitive in certain lines of computer products (such as laptops), and posed a significant threat to continued American dominance in this crucial high-tech industry. 58 One consequence was American pressure on Japan to open its domestic market in the products (e.g., integrated circuits) where the United States still led Japan.

\footnotetext{
${ }^{57}$ The following description of the negotiation of the semiconductor agreement and auto parts negotiations draws from a paper by myself and Ellis Krauss entitled 'Ideology, Interests and International Trade: MITI and Japan's Response to American Trade Friction'. The paper was presented on a panel entitled 'Nationalism and Internationalism in US-Japan Trade Friction: Structure Process and Outcomes' at a Joint Conference of the Japan Association for International Relations and the International Studies Association held in Makuhari, Japan, 20-22 September 1996.

${ }^{58}$ Clyde V. Prestowitz, Jr. Trading Places ( New York: Basic Books, 1988), pp.44-46.
} 
Japanese officials argued that this represented a move towards managed trade and resisted American pressure. But eventually they agreed to a target of a 20 percent share for American producers and offered to co-operate with American government officials in order to achieve that goal by encouraging the growth of Japanese consumer demand for American products. The 1986 Semiconductor Agreement was signed. ${ }^{59}$ An immediate conflict developed over the interpretation of the agreement whether the 20 percent figure was a numerical target or, more emphatically, a guaranteed market share. The Japanese insisted it was just a vague objective but American officials used regular assessments about market distribution and numerical targets as rallying points to pressure their Japanese counterparts.

Having learned a valuable lesson from the semiconductor agreement, Japanese officials refused to enter into this same type of agreement when American officials (under the Bush Administration) adopted a similar posture in regards to the Japanese auto parts market in 1990. By 1993-1994 (now the Clinton Administration), the Japanese position was firm.60 Hatakeyama Noboru, MITI Vice Minister for International Affairs, summarised the Japanese position succinctly when, in the midst of the discussions over auto and auto parts, he stated, "we have learned a lesson. Once reference is made in a trade agreement to numerical figures, then those figures will get a life of their own. So we will never repeat this type of thing, to avoid misunderstandings and managed trade". 61 I. M. Destler insightfully commented on the significance of numerical agreements when he stated that "the U.S. doesn't trust Japan to do things without numbers ..... and Japan doesn't trust the U.S. with numbers".62

\footnotetext{
${ }^{59}$ On the first two semiconductor agreements of the early 1980s, see Prestowitz op.cit., pp.50-61; on the more famous 1986 agreement, see Krauss, op.cit., p.271.

60 The contrast between an overall multi-lateralist posture (consistent with a 'just like us' posture) and a managed trade position by the Clinton Administration in the case of the auto industry is made by Jagdish Bhagwati, 'The US-Japan Car Dispute: A Monumental Mistake', International Affairs, 72, 2, (1996), pp.261279. For a history of this dispute see also Susan McKnight, 'U.S.-Japan Competition in Automotive Parts: No Quick Fixes' (April 23, 1993), Japan Economic Institute Report number 15A.

61 Hatakeyama Noboru quoted in, T.R. Reid and Paul Blustein, "Saying No to America: Japan Adopting Tough New Trade Position As U.S. Does Same Thing, Fuelling Friction", Washington Post, April 25, 1993, p.A28.

62 I. M. Destler quoted in Bob Davis, "Kantor Hopes Japan's Cabinet Officials Can Forge Compromise in Trade Talks", The Wall Street Journal, 1 February 1994, p.A2.
} 
Japanese officials therefore refused to specify any quantitative targets for American firms in Japan, insisting that the notion of voluntary targets had been reinterpreted by their American counterparts as firm and enduring commitments that represented an abrogation of the principle of free trade in favour of the protectionist principle of 'managed trade'. The only figures the Japanese were willing to discuss, according to Sozaburo Okamatsu, Deputy Minister for International Trade and Industry, "would be evaluations of past trade statistics to determine whether progress has been made, not to set goals for importing American goods." 63

The Japanese counterproposal entailed three components. These were deregulatory in character, involving a series of industry-to-industry informal and flexible agreements; a series of provisions designed to provide American firms with greater opportunities to market their products as the negotiations developed, such as changes in the rules governing aftermarket sales and inspection laws; and changes in the notorious laws regarding certification of the safety of vehicles in Japan. 64 Ironically, these measures were far more consistent with a ‘just like us' strategy than a 'different capitalism' one. 65

Japanese negotiators resolutely maintained that agreements based on numerical targets were "totally beyond government control". 66 Consumers, MITI officials claimed, are the ones who decide what to buy in Japan. 67 Hiroshi Kumagai, MITI Trade Minister, called on the companies of both nations to work together to ease friction and even Jeffrey Garten, then U.S. Undersecretary for International Trade, emphasised that private sector efforts were the key to increased foreign sales in Japan. 68

\footnotetext{
63 James Sterngold, “Japan Trade Talks: Good Will Meets Bureaucracy”, New York Times, 16 January 1994, p.3.

${ }^{64}$ See "Car Talks Still Stall on the Setting of Targets", Japan Times, 21 October 1993, p.2; Schoppa Jr. op.cit., p.414; McKnight, op.cit., p.5.

65 See, for example, the comments of Akitane Kiuchi, Japanese government official, in "Japanese Chief Due in the U.S., Faces Impasse", New York Times, 10 February 1994, p.A1; Steven Greenhouse, "U.S. Warns Japanese Over Trade", New York Times, 15 January 1994, p.17; and Andrew Pollack, New York Times, 31 January 1994, p.C2.

66 Schoppa Jr. op.cit, p.406.

67 "Car Talks Still Stall on the Setting of Targets", Japan Times, 21 October 1993, p.2.

68 See Pollack, Andrew, "U.S. and Japan Study Private Panel on Trade", New York Times, 3 February 1994, p.C8.
} 


\section{The Current Context of Japanese Reforms: Optimists, Pessimists and Revisionists.}

With few exceptions, American policymakers and academics seem convinced that the Japanese economy is structured differently from their own and that it is in serious trouble. While many American 'revisionists' formerly characterised the Japanese as posing an economic threat to the stability and capacity of the American economy in the form of global high technology leadership and the loss of domestic manufacturing sectors (and with that the loss of jobs), less do so now. Clyde V. Prestowitz jr., once an official at the US Trade Representatives office and formerly an unabashed nationalist in hyping the threat posed by Japan, has recently and publicly repeatedly conceded that he was incorrect and overstated the predatory instincts and challenges posed by Japanese producers. Robert Rubin, Treasury Secretary and key figure in bilateral policy co-ordination, has referred to the state of the Japanese economy as a "morass". ${ }^{69}$ The overwhelming majority of American politicians, academics and pundits are now more concerned with the question of how to get the Japanese economy reinvigorated, rather than how to slow down its prowess. ${ }^{70}$ Indeed, they fear that the Japanese economy's problems might bring itself and the U.S. economy down. In that sense, the current fears of global economic 'meltdown' are perceived as a greater threat by Americans than the former, more parochial concerns about American competitiveness.

Yet these same people disagree on how to respond to Japan's longstanding problems when it comes to trade matters. There are a series of positions that they might adopt, their views largely being divided between what might be termed 'optimistic' and 'pessimistic' assessments of the Japanese economy, and the contingent scenarios that consequentially follow.

\footnotetext{
${ }^{69}$ Rubin quoted in http://biz.yahoo.com/finance/980710/asia_risk_1.html

${ }^{70}$ It should be recognised that exceptions to this generalisation remain, notably in the form of a core of academics who argue that the Japanese bureaucracy is in a process of adaptive transition in responding to a new context but retain a distinct capacity to meld the Japanese economy effectively. Among the best work of this group is that by Steven Vogel, Freer Markets, More Rules (Ithaca, NY: Cornell University Press, 1997). A similar theme, though broader empirically, is developed by Paul Doremus et. al., op. cit.
} 
The American optimists. Proponents of this position assume that the forces of globalisation have punished Japan for its failure to conform to the discipline of the marketplace in the halcyon years of the 'bubble' when cash was readily available for loans and real estate prices grew at a phenomenal rate. They contend that, whether voluntarily or 'kicking and screaming', Japan will adapt. The cost of not doing so is too high, already evident in the sustained credit crunch and new recessionary conditions currently being experienced in Japan.

The optimists tend to assume that Japan can and will undergo reform (and may indeed be doing so already). The result of this process is that Japan will begin (or has begun) to assimilate an Anglo-American institutional pattern -- both in economic and in political dimensions -- moving Japan away from the lethargy, confusion and stasis of the last decade.

The American optimists, focusing on the economic dimensions, point to the importance of deregulation, particularly that of the financial sector, as evidence of change in the direction of 'market style' (i.e. Anglo-American) capitalism. The tone of this position is reflected in a recent New York Times report where the day's leading story on the imminent Japanese financial deregulation began with the assessment that:

In one of its most ambitious undertakings, the Japanese government plans to set in motion a far-reaching program that it hopes will infuse the country's financial landscape with the prowess of its manufacturing industries. The rules of the game start changing Wednesday in a phased, three-year process called the Big Bang. For the Government of Prime Minister Ryutaro Hashimoto, April 1 is the opening shot in an effort to transform Tokyo into a financial center as vibrant as New York or London. ${ }^{71}$

Optimists point to further plans to deregulate such former stalwarts of the public sector as the Japan National Railways, where prior efforts to do so were incomplete at best and disingenuous at worst, as evidence to support their claim that Japan is moving away from 
public sector involvement. These changes, they contend, represent a real reformist impulse. Among this group is included Jeffrey Sachs, who sees American claims of inactivity as misplaced and genuine deregulatory and market-opening measures taking place in Japan's markets. ${ }^{72}$ Another is Alan Greenspan who has stated that he believes, more generally, that the crises in East Asia will have the effect of stimulating the convergence of these economies towards an Anglo-American model. ${ }^{73}$ In this context, this group approves of the current 'bridge bank' plan to get rid of insolvent financial institutions as a further step towards enforcing market mechanisms in the Japanese economy. ${ }^{74}$

The governmental counterpart to this Japanese deregulatory process is a stress on ever-larger macro-economic fiscal stimulus packages. The most recent stimulus programs, announced by former Prime Minister Hashimoto in April of 1998, proposed expenditures totalling US\$75 billion (which represents about 2 percent of total annual economic output). Part of that sum would be spent on public works projects in areas like environmental protection, nursing, care for the aged, science and technology, and telecommunications projects. The largest portion of that $\$ 75$ billion, however, would be spent in the form of tax cuts. An additional US\$45 billion in funds would be made available for loans and land purchases. ${ }^{75}$ Yukihiko Ikeda, former Japanese foreign minister, suggested that additional expenditures on infrastructural investment and measures to support the Asian economy could push the total up to $\$ 240$ billion. $^{76}$

The goal of the majority of this expenditure is to increase domestic consumption, although evidence suggests that Japanese consumers will save the extra funds rather than spend them. ${ }^{77}$ Smaller tax cuts in 1997 resulted in a 3 percent increase in savings rather than greater private

\footnotetext{
${ }^{71}$ Sheryl WuDunn, 'Japan to Rev Up the Economy, Prepares to Reshape Its Markets', New York Times, 31 March 1998, p.A1.

${ }^{72}$ Jeffrey Sachs, 'Danger in Flogging Japan', The Financial Times, 24 April 1998, p. 20.

${ }^{73}$ Alan Greenspan speech to the Annual Convention of Independent Bankers Association of America, 3 March, 1998, http://bog.frb.fed.us/board/docs/speeches/19980303.htm.

${ }^{74}$ See 'Clinton Exudes Confidence Towards Japan', Yahoo.com/headlines/upi/story.html?s=n/upi/98/07/03/i.../japanclin_1.htm

${ }^{75}$ Sheryl WuDunn, 'Japanese Premier Seeks \$75 billion to Spur Economy’, New York Times, April 101998, p.A1.

${ }^{76}$ Comments by Yukihiko Ikeda, former Japanese foreign minister, on a panel entitled 'Does Japan Need a Miracle?' on May 6 at the ESI's seventh annual trade conference entitled 'Whither Globalism: A World in Crises?', the Hyatt Regency in Washington DC on 5-6 May 1998.
} 
expenditures. Nevertheless, for optimists, the current opportunity is not illusory, largely as a result of the market forces of globalisation and the related pressure caused by the various financial crises in the region. If the source of the problem is mismanagement by both the public and private sectors, the cure lies in better management - of the type seen in Taiwan where the focus has been on flexibility, sound fiscal management and progress towards political reform.

What do the Americans recommend in more practical terms? The adverse effect on the U.S. of Japan's problems, declared Thomas Foley (current American ambassador to Japan), is already becoming apparent; a trend in declining U.S. exports to Japan and growing Japanese bilateral surpluses with the U.S. sharply accelerated in the Spring and Summer of 1998 compared to last year. Japan, as Asia's locomotive, is key to the region's revival and "true deregulation" is key to Japan's rejuvenation - as is evident in the benefits now enjoyed by Japanese consumers in the form of lower prices in areas such as telecommunications and airline tickets. More effort is needed to install a "pro-competitive regime" in areas like medicine, housing construction, pharmaceuticals, and finance. Such a regime would create transparency and, with it, dynamism. Foley feels optimistic that a consensus is emerging in Japan in support of such widespread changes. ${ }^{78}$ He forecast that a change of leadership won't diminish that impulse. ${ }^{79}$

Notably, in terms of the theme of this paper, Kenneth Courtis (the Chief Strategist for the Deutsche Bank Capital Markets) recently contended that "the resolution of the Asian crisis begins in Washington and Tokyo". The other afflicted countries such as Thailand, Korea and Indonesia are largely caught in a tidal wave that they contributed to but was not a product of their own making. ${ }^{80}$

\footnotetext{
${ }^{77}$ Sheryl WuDunn, 'Japanese Premier Seeks $\$ 75$ billion to Spur Economy', op. cit.

${ }^{78}$ Comments by Thomas Foley, U.S. Ambassador to Japan, on a panel entitled 'Does Japan Need a Miracle?' on May 6 at the ESI's seventh annual trade conference entitled 'Whither Globalism: A World in Crises?', the Hyatt Regency in Washington DC on 5-6 May 1998.

${ }^{79}$ See Foley quoted in 'US-Japan relations will stay after Hashimoto-Foley', http://www.yahoo.com/M=B1000.134381.1224968.6161/D=finance/S=7811756:N/A=67039/?http://www.yaho o.com/promotions/online/7.html.

${ }^{80}$ Comment by Kenneth Courtis on a panel entitled 'The Hot Zone: Causes and Cures of the Asian Contagion' held on May 6 at the ESI's seventh annual trade conference entitled 'Whither Globalism: A World in Crises?', the Hyatt Regency in Washington DC on 5-6 May 1998.
} 
In contrast to the claims of economic reform, relatively few contend that the Japanese political system has undergone significant reform towards an Anglo-American model. But even here we can locate modest impulses. Several obvious factors contribute evidence towards sustaining such a claim. The first is the electoral defeat of the Liberal Democratic Party (LDP) after four decades of uninterrupted power twice during the current decade, and the sharing of power such defeats have entailed. Linked to this is a subsequent crisis in the LDP's party leadership after each electoral setback. Finally, and, perhaps most profoundly, is an apparent breakdown in the traditional post-war distribution of power between a dominant bureaucracy, a weak set of (purportedly corrupt) politicians, and a compliant private sector. ${ }^{81}$ While rich debates have raged about the shifting contours of this relationship for the last decade-and-ahalf, it appears genuine that something fundamental is happening to that relationship in Japan. ${ }^{82}$ The most provocative and compelling formulation of this argument to date is that offered by T.J. Pempel, who suggests that, stirred by the these very factors, a 'regime shift' is occurring in the nature of the Japanese polity, one that may fundamentally alter the relationship between these actors. ${ }^{83}$ The surprise electoral showing of the LDP in the July 1998 elections, and Hashimoto's subsequent resignation can alternatively be interpreted as consistent with Pempel's analysis or part of a continued cycle of weakened leadership, depending on the policies of his successor Keizo Obuchi. But Obuchi's record was the least

\footnotetext{
${ }^{81}$ See, for example, Sheryl WuDunn, 'Politicians Take on Japan's Finance Ministry, With Caution', New York Times, September 26, 1998, p.C4; Nicholas D. Kristof, 'Status of Elite Bureaucrats Declines as Japan Does', New York Times, 17 April, 1998, p.A1.

${ }^{82}$ This literature is far too extensive to cite exhaustively here but, for the best examples reflecting a variety of views see James C. Abbegglen and George Stalk, Jr., Kaisha: The Japanese Corporation (New York: Basic Books, 1985); Marie Anchordoguy, "Mastering the Market: Japanese Government Targeting of the Computer Industry." International Organization, 42,3 (Summer 1988), pp.509-543: Kent. E. Calder, Strategic Capitalism: Private Business and Public Purpose in Japanese Industrial Finance (Princeton, NJ: Princeton University Press, 1993); Chalmer Johnson, op. cit.; Ellis S. Krauss and Michio Murumatsu, 'The Conservative Policy Line and the Development of Patterned Pluralism in Japan. Kozo Yamamura and Yasukichi Yasaba (eds.), The Political Economy of Japan, Volume 1: The Domestic Transformation, (Stanford: Stanford University Press, 1987); Hugh Patrick and Henry Rosovsky, eds., Asia's New Giant: How the Japanese Economy Works. (Washington: Brookings, 1976); Daniel I. Okimoto, Between MITI and the Market: Japanese Industrial Policy for High Technology (Stanford, CA: Stanford University Press, 1989); T.J. Pempel, "Japanese Foreign Economic Policy: The Domestic Bases for Economic Behavior," in Peter J. Katzenstein, ed., Between Power and Plenty, (Madison: University of Wisconsin Press, 1978), pp.139-190; Richard J. Samuels, The Business of the Japanese State: Energy Markets in Comparative and Historical Perspective (Ithaca, NY: Cornell, 1987); Ezra F. Vogel, Comeback (New York: Simon and Schuster, 1985). A good overview of this literature is provided by Gregory W. Noble, "The Japanese Industrial Policy Debate," in Stephan Haggard and Chung-in Moon, eds., Pacific Dynamics: The International Politics of Industrial Change, (Boulder, Col: Westview, 1989), pp. 53-95.

${ }^{83}$ See T.J. Pempel, "Regime Shift: Japanese Political Economy in a Changing World Economy." Journal of Japanese Studies, 23, 2 (Summer, 1997). This argument is expanded in his forthcoming book: Regime Shift: Comparative Dynamics of the Japanese Political Economy, (Ithaca, NY: Cornell University Press, 1998).
} 
ambitious of the three candidates who stood for the LDP's leadership, offering the prospect of little change, and early analysis suggested that the United States was unlikely to let up in its pressure on the new government. ${ }^{84}$ Nevertheless, a Financial Times column implicitly supported Pempel's views when it stated that "paradoxically, the sheer scale of Mr. Hashimoto's humiliation may be what Japan needs. The traumatised LDP may now be willing to allow swift and dramatic action. Anti-Hashimoto politicians, who have called for the loosening of the financial purse strings, could now have an unprecedented opportunity to put their criticisms into practice. If so, the markets may remember that in other battered Asian economies, a change in political leadership was needed to effect economic reform. Japan may be no different." 85 One possibility may be that Obuchi's election may increase the prospect of a split within the LDP and enhance the likelihood of an early general election. ${ }^{86}$

Yet, despite the events surrounding Hashimoto's resignation, Pempel's voice at this stage, is a fairly solitary one in a world where academics and commentators remain sceptical about any real initiative or will among Japan's political leadership. It may nevertheless prove to be a prescient one in the near future.

The Pessimist's. A second, less sanguine response exists among American academics, analysts and members of the policy community on the possibilities for Japanese rejuvenation. Its proponents concur with the optimists in arguing that the Japanese economy (and indeed its polity) is different in its form and values from the Anglo-American model -- and that is the root of its problems. Transgressing the laws of the marketplace through 'bubble economics' and corrupt business and political practices, these critics contend, has brought the problems of Japan upon itself. The same is true of the rest of troubled Asia, Suharto's flagrant nepotism, in their view, being the central example of the vices of Confucian capitalism. As William Safire offered this criticism, in perhaps its boldest form, comparing Asian capitalism to other forms generally considered more pernicious:

\footnotetext{
${ }^{84}$ Linda Sieg, 'ANALYSIS-US won't ease pressure over Japan economy', 27 July 1998, http://biz.yahoo.com/finance/980727/japan_poli_2.html.

${ }^{85}$ The Lex Column, 'Made (and Broken) in Japan', Financial Times, 13 July 1998, p.20.

${ }^{86}$ See 'Japan MP warns of ruling party split on Obuchi win', http://biz.yahoo.com/finance/980724/japan_poli_1.html.
} 
The dictatorial model, driven by mutual back-scratching of elites rather than a profit motive open to all, rewarded despotism and nepotism at the expense of efficiency and transparency. Now eyes are opening all over the world to the realisation that the gravy train does not run on time. Communism, socialism, fascism and 'crony capitalism' not only interfere with the free flow of capital to the best producer, but deny the consumer the right to decide which products succeed. Once again autocrats and their acolytes are learning that government's business in business is to protect competition in business. ${ }^{87}$

But, unlike the optimists, when faced with the challenges posed by globalisation and the recent regional crises, pessimists argue that Japan may well fail to respond to these exigencies. As Brian Bremner recently commented, portraying a disapproving tone and offering a radical prescription:

[F]iscal stimulus, however deep, may not do much to resolve the Japanese crisis at this point...JJapan faces a debt trap of its own making that involves the banks, households, and corporations of the whole nation. Japan must dismantle this trap. Otherwise, its struggles could weaken the yen further and destabilise the world economy, forcing other Asian nations to devalue and eventually hurting U.S. exports. A dysfunctional Japan could slow global growth for years......... The problem is not just the reported $\$ 600$ billion in bad loans that plague the nation's banks.......hundreds of billions of dollars of debt that lurk off the balance sheets of government bodies and corporations... millions of families struggling to pay off mortgages on houses that have lost $70 \%$ of their value... billions of dollars in pension liabilities that no one wishes to acknowledge and $\$ 700$ billion in offshore liabilities of Japan's banks and corporations...........no one in Japan knows the full extent of the problem, no one can predict where the bottom

${ }^{87}$ William Safire, ‘Gravy Trains Don't Run on Time’, New York Times, 19 January, 1998, p.A15. 
is.......no Western nation needs to grapple with the problem of hidden, unmeasured debt in the way Japan does." 88

Clyde Prestowitz jr. clearly offered a disquieting perspective when he pointed to Japanese confusion and impotence in suggesting that 'the crazy thing is that the Japanese could take care of it, but they aren't doing anything". ${ }^{89}$

Adopting a flagrantly sweeping tone, another observer recently suggested that the solution was "clean banks and a hard currency", not allowing volatile currency fluctuations to sustain export-oriented policies. ${ }^{90}$ Rather than pursuing such policies, however, critics contend that Japanese officials will rely on traditional policy options such as export-led growth that the critics dismiss as inappropriate and unlikely to yield significant results.

This vein of opinion is likely to be given new vitality in view of the predictable ballooning of the American bilateral trade deficit in Japan in the context of the yen's recent decline. Indeed, by April of 1998, the US deficit with Japan was running at a monthly figure of $\$ 5.4$ billion, 13.3 percent ahead of the same period in $1997 .{ }^{91}$ The seasonally adjusted figures for May showed a record overall trade surplus for the Japanese economy, as the weak yen assisted in widening the gap between sluggish domestic demand and strong exports. ${ }^{92}$

Offering ineffectual responses (or ignoring the problem altogether), they contend, will presage a further tumultuous decline in the fortune of the Japanese economy, the Asian economy, and - potentially - the global economy. Charlene Barshefsky recently echoed this

\footnotetext{
${ }^{88}$ Brian Bremner, ‘Japan's Real Crisis', Businessweek, May 18 1998, pp.136-138.

${ }^{89}$ Prestowitz cited in Bremner, op. cit., p.138.

${ }^{90}$ Comment by Rudiger Dornbusch on a panel entitled 'The Hot Zone: Causes and Cures of the Asian Contagion' held on May 6 at the ESI's seventh annual trade conference entitled 'Whither Globalism: A World in Crises?', the Hyatt Regency in Washington DC on 5-6 May 1998.

${ }^{91}$ For the entire Pacific Rim region, which includes South Korea and other countries hard hit by the currency crisis, the U.S. trade deficit in the first four months of 1998 totalled $\$ 48.7$ billion, 38 percent higher than the prior year's figure for the comparable period. For both the bilateral and regional figures see http://www.msnbc.com/news/174015.asp\#BODY.

92 See Daniel Dombey, 'Currencies: Yen Holds on While Sterling Soars', Financial Times, 19 June 1998.
} 
view when she suggested that Japan risked not playing a global role and thus failing to take sufficient responsibility for regional stability. ${ }^{93}$ Pessimists largely reject the notion that IFIs pursuing the neo-liberal agenda with too great a relish may exacerbate regional problems and have a long term disquieting effect on policy co-ordination in the region.

Proponents of this pessimistic position thus argue that the Japanese system may well be beyond repair. Those same American critics are quick to explain why what happened in Japan cannot happen in the United States; the "quality of its economic policy", reflected by "whether policymakers can address the problems". 94 They believe that Japanese banks, saddled with a mountain of bad debt, dare not reveal the full extent of the problem for fear that such exposure would bankrupt these institutions and shake the entire system to its foundations. When recently questioned on this matter, James Wolfensohn, President of the World Bank, sheepishly described Japanese banks as having been 'nominally compliant' in terms of adhering to disclosure laws. ${ }^{95}$ Both the government and the banks would rather hide the problems, critics contend, and avoid the consequences. Reported suicides by banking officials provides a glimpse of the tear in the social fabric. But, these American critics suggest that -- comparable to the American response in the Savings and Loan crisis of the 1980 s -- it would be better to reveal the extent of the problems facing the Japanese financial system, take the punishment and then begin the process of rebuilding. Japan, they add, will not do so to their ultimate detriment. ${ }^{96}$

In practice, pessimists argue that government measures should include five components. These consist of an independent audits of banks; the introduction of transparent accounting systems; a rewriting of the tax code; public disclosure of the true level of the off-book liabilities of the Zaito budget controlled by the Finance Ministry; and the withdrawal of postal saving and pension funds to support the stock and property markets. ${ }^{97}$

\footnotetext{
${ }^{93}$ Charlene Barshefsky spoke at a conference organised by the Economic Strategy Institute entitled 'Whither Globalism: A World in Crises?' held at the Hyatt Regency in Washington DC, on May 51998.

${ }^{94}$ See Michael J. Mandel, 'Why America won't be next', Businessweek, 18 May 1998, p.140.

${ }^{95}$ Wolfensohn was speaking at a conference organised by the Economic Strategy Institute entitled 'Whither Globalism: A World in Crises?' held at the Hyatt Regency in Washington DC, on 5 May 1998.

${ }^{96}$ See Linda Sieg, 'Asia Focus: Japan Economy - Breakdown or Makeover?', 10 July 1998, biz.yahoo.com/finance/980710/asia_risk_1.html.

${ }^{97}$ Bremner, op.cit., p.142.
} 
The consequences of such actions, pessimists contend, would be multifaceted. Consistent with a neo-liberal economic perspective, only the financially secure firms would survive. Market access would be secured for foreign investors and, as a result, Japanese consumers of financial services would be provided with further access to viable investment opportunities, instead of leaving their money in largely in post office accounts that pay little by way of dividends and is unproductive capital for investors. The pace of Japan's financial big bang would therefore be accelerated. Japan must, American pessimists insist, "restructure its economy toward a model that favours domestic demand, and stop trying to export its way out of trouble at the expense of the rest of Asia." 98

According to pessimists, this policy response would therefore yield general benefits as it moved Japan away from the politics of productivity to that of consumption. Those who would not benefit are threefold. First, the Japanese state, whose bureaucrats now have access to all that cash in those post office accounts at cheap rates as a policy instrument -- and the enormous leverage that goes with such access. Second, those domestic firms who are direct beneficiaries of this system, such as the major construction companies that have historically garnered all those lucrative infrastructure contracts as the government attempts to spend its way out of a deflationary environment. Third, those public and private sector officials who personally benefit from all the slush money that swills around Japan, fuelling the sharply criticised 'crony capitalism'.

Accompanying these flaws in the economic system, pessimists contend, are equally onerous and imponderable problems in the political system. In addition to blatant and widespread corruption, these include too much discretionary bureaucratic power and a related lack of transparency in economic affairs, along with a weak and flaccid party system. In sum, some critics contend, nobody really 'rules' Japan in a traditional sense; the country is confused and unwilling or unable to change course. ${ }^{99}$ American critics call for "the rule of law" instead of

\footnotetext{
${ }^{98}$ See, for example, Clyde V. Prestowitz Jnr., 'Asia's Flawed Fundamental', Fortune Magazine, 13 April 1998.

${ }^{99}$ Comment by Rudiger Dornbusch on a panel entitled 'The Hot Zone: Causes and Cures of the Asian Contagion' held on May 6 at the ESI's seventh annual trade conference entitled 'Whither Globalism: A World
} 
rule by what they see as by fiat and political logrolling. ${ }^{100}$ Rudiger Dornbusch, Professor of Economics and International Management at the Massachusetts Institute of Technology, summed up a common American view of Japan's economic and political system when he bluntly stated that "bankers would go to jail in New York for doing what they do in Japan or in the Congress what they do in the Diet". Hashimoto, the Japanese Prime Minister, needs to be "kicked out" and a ten-year restructuring process initiated. ${ }^{101}$

Indeed, sweeping political and economic reform, pessimists contend, would have a significant short-term cost but enormous long-term benefits. Yet is it the very fact of this short-term cost, pessimists warn, that will preclude serious Japanese action in the absence of strenuous and extended foreign pressure. Both foreigners and Japanese contemplate whether the resignation of Hashimoto will expedite or retard the pace of reform. ${ }^{102}$

Many of these themes were evident at a recent conference of major American luminaries drawn from the ranks of government, industry, policy think tanks and the academic community, organised by the Economic Strategy Institute and held in Washington DC in early May of 1998. ${ }^{103}$ Edward Yardeni, chief economist at Deutsche Morgan Greenfield, left the audience in no doubt of his views and perhaps best summed up the sentiment of the conference when he declared that "capitalism defeated communism and now it is defeating corruption in Asia". "If the Asian problem is corruption", Yardeni suggested, then "Japan is

in Crises?', the Hyatt Regency in Washington DC on 5-6 May 1998. These comments echo the sentiment express by Karel van Wolferen, The Enigma of Japanese Power (New York: Alfred Knopf, 1989).

${ }^{100}$ Ibid.

${ }^{101}$ Comment by Rudiger Dornbusch on a panel entitled 'The Hot Zone: Causes and Cures of the Asian

Contagion' held on May 6 at the ESI's seventh annual trade conference entitled 'Whither Globalism: A World in Crises?', the Hyatt Regency in Washington DC on 5-6 May 1998.

${ }^{102}$ Miki Shimogori, 'FOCUS-Japan, US business urge swift Japan action', 13 July, 1998, http://biz.yahoo.com/finance/980713/japan_elec_14.html.

${ }^{103}$ The ESI's seventh annual trade conference was entitled 'Whither Globalism: A World in Crises?' and was held at the Hyatt Regency in Washington DC on 5-6 May 1998. Included among the ESI's major officials are Clyde V. Prestowitz Jnr. and Lawrence Chimerine, both of whom are noted for their hardline position on trade issues. Speakers at the conference from the present and former ranks of the American government included $\mathrm{Al}$ Gore, Richard Gephardt, Ira Magaziner, Charlene Barshefsky, Franklin Raines, Tom Foley, Jeff Bingaman, Brent Scowcroft, Joseph Lieberman, Larry Summers and Thomas 'Mac' McLarty. Countless representatives from the senior ranks of American industry participated, including Andrew Groves of Intel, Steve Case of America Online and Glenn Fukushima who is the president of the American Chamber of Commerce in Japan. Invited foreign speakers included Jacques Santer (still then president of the EU), James Wolfensohn (President of the World Bank) and Li Zhaoxing, the PRC's Ambassador to the United States. 
the epicentre of global deflation and corruption". ${ }^{104}$ The product, the pessimists at the conference concurred, will be that the situation in Japan will get worse and Asia will enter into depression. ${ }^{105}$

A Dissident 'Unreconstructed Revisionist' View from the U.S. Side. Finally, it should be noted (in more than passing) that a dissident voice exists to both of these positions among Americans. This is the perspective of the true comparative capitalists - those who argue that systems are different but that this is no bad thing. In fact a rich literature exists that substantiates the view that different countries respond to systemic forces in different ways as a result of ideological proclivities, institutional constructs or interest structures. ${ }^{106}$ In contrast to both of the prior views discussed, however, this is not assumed to be a normatively 'bad thing. Nor does it presuppose that a Japanese prescription to their current situation that rejects the assumptions of neo-liberalism is doomed to failure. In contrast, advocates of this alternative way suggest that the Japanese have historically found ways to adapt to external pressures and, although their voice certainly remains muted in the U.S. press at the moment, they may find a way to do so now.

This third view contends that the Japanese will only institute incremental reforms (if at all) but these may well be to good effect. Such a position rejects the common assumption of the optimists and pessimists that neo-liberal reform is the only remedy to Japan's problems. Rather, Japan has historically found its own way to marry capitalism and democracy precisely the construct that critics have pejoratively identified as founded on 'Asian values',

\footnotetext{
${ }^{104}$ Edward Yardeni expressed these views as a speaker on a panel entitled 'Is the U.S. Economy Really Different? A Debate', 'Whither Globalism: A World in Crises?', Hyatt Regency in Washington DC, 5 May 1998.

105 These views were expressed by John D. Schilling, Secretary, Operational Policy Committee, the World Bank and Rudiger Dornbusch on a panel entitled 'The Hot Zone: Causes and Cures of the Asian Contagion' held on May 6 at the ESI's seventh annual trade conference entitled 'Whither Globalism: A World in Crises?', the Hyatt Regency in Washington DC on 5-6 May 1998.

${ }^{106}$ The list of such work is far to long to cite here but, among the more distinguished works includes Peter Katzenstein, (ed.), Between Power and Plenty; Peter Hall and Rosemary Taylor, 'Political Science and the Three New Institutionalisms', Political Studies, (1996), XLIV, pp. 936-957; Peter Hall, Governing the Economy; Barrington Moore, Social Origins of Dictatorship and Democracy; Theda Skocpol, States and Social Revolutions; Peter Katzenstein, Small States in World Markets; Peter Gourevitch, Politics in Hard Times; Phillipe Schmitter, "Still a Century of Corporatism?" in Review of Politics, Vol.36, 1 (January, 1974); Theda Skocpol, "Bringing the State Back In: Current Research" in Peter Evans, et. al. (eds.) Bringing The State Back In; Alexander Gerschenkron, Bread and Democracy in Germany; Richard Samuels, Rich Nation, Strong Army.
} 
or labelled as 'Confucian capitalism', 'the Singapore model' or, most stingingly, 'crony capitalism'.

Chalmers Johnson is among the most notable proponents of this counterintuitive approach in which the distinctions between types of capitalism are recognised while not being treated with as a sign of the failing of Asian economies. Indeed, there are features of both the Asian models (really only Japan and South Korea according to Johnson) and the Anglo-American economies that are simultaneously shared and distinct. But, in contrast to the assumptions of the other two American positions, Johnson suggests that some of the undesirable components of these East Asian economies are common to its Anglo-American counterpart while the virtues of those same Asian economies are often discrete and not shared.

In a forthcoming article to be published in the Cambridge Journal of Economics, Johnson offers a forthright defence of Asian variants of capitalism while systematically attacking what he considers to be the cronyism of Western governments. As Johnson says:

I take crony capitalism to mean corruption, nepotism, excessive bureaucratic rigidity, and other forms of trust violation that can occur whenever a state tries to manipulate incentives or, in other ways, alter market outcomes. The system of tax deductions for household mortgages in the U.S. is a standard example of this form of state guidance of the market. Crony capitalism is said to promote many sins, including the overbuilding of real estate throughout the region and the excessive importing of consumer goods, such as luxury automobiles - that is the kinds of thing the Mexicans did a few years ago when foreign financial institutions poured money into their country.........The ultimate in crony capitalism is actually the U.S.dominated International Monetary Fund (the IMF) and its bailing out of Thailand, Indonesia, and South Korea; the IMF's money does not go to the people of those countries. It goes to the foreign banks that made too many shaky and imprudent loans to Thai, Indonesian, and South Korean banks and businesses in the first place. 
Furthermore, Johnson is a current rarity in attacking any suggestion that the troubled economies of Asia should accept neo-liberal assumptions:

Throughout the region, the current crisis was caused much more by underregulation than by corruption or any other side effects of an overly close relationship between businesses and the government. What all these places need is neither more nor less regulation but effective, expert guidance of the sort Japan and South Korea exercised during their periods of highspeed economic growth.

While Johnson does admit that Japan is fairly accused of crony capitalism, it is identifying both the source of and the solution to Japan's problems where he contrasts with both American optimists and pessimists:

Ever since Japan's bubble economy started to deflate in 1989 and 1990, Japan has complacently continued to protect its structurally corrupt and sometimes gangster-ridden firms and has made only gestures toward holding anyone responsible. Virtually all of its public funds to stimulate the domestic economy have gone to the politically powerful but environmentally disastrous construction industry. Japan has been able to get away with palliatives largely because of the perpetuation of Japan's cosy Cold War relationship with the United States. This means that Japan is not being forced to make the painful choices that adjusting to a global economy would require. Japan remains today essentially a protectorate of the United States, not fully in charge of its own government or destiny. When that changes, Japan will change.

According to Johnson, American policy is the source of Japan's problem, rather than part of any solution. He remains unapologetic for the "structures of Asian capitalism", contending that:

These structures include cartelisation of the keiretsu-chaebol variety, bankbased systems of capital supply, mercantilism and protectionism vis-à-vis 
external economies, and rule by bureaucratic elites despite a pretence of democracy. The intent of these structures was to enrich the nations of East Asia, not to meet consumer demand, global efficiency, individual choice, or any of the other motives posited by neo-classical economics. That they succeeded so spectacularly during the historical era known as the Cold War altered the world balance of power.

While crony capitalism has been an unfortunate side effect of the development of capitalism in Asia, Johnson argues that it has similarly afflicted the U.S. in the 1990s, buying political influence in Washington and ambassadorships throughout the world. Why then, has it not led to the demise of this regime? Furthermore, and most pointedly for the themes of this paper, Johnson denies that the revisionists have been repudiated in their views by events and the laws of neo-classical economics.

Western economists, unable to explain Japan's growth or, for that matter, even to read a Japanese newspaper, rejected so-called revisionism because its findings were incompatible with orthodox neo-classical economic theory. The disaster of $1997 \mathrm{did}$ not refute revisionism but rather confirmed the essence of the revisionists' messagethere are differences among capitalist systems that are not trivial and that under the right circumstances can blow the system apart.

Johnson concludes his comments by suggesting that the major flaw in the revisionist argument is that they didn't go far enough in recognising or appreciating the differences between the Anglo-American and East Asian forms of capitalism, notably in Japan. Convergence is neither possible nor desirable:

...No amount of foreign money or pressure will cause Japan to reform. Only cutting its apron strings to the U.S. will energise the Japanese political system. If that happens we are likely to see a renewed burst of growth and prosperity throughout the region. If not, global recession is a serious possibility. ${ }^{107}$

\footnotetext{
${ }^{107}$ All these citations are found in a forthcoming article to be published by Chalmers Johnson entitled 'Economic Crisis in East Asia: The Clash of Capitalisms' in the Cambridge Journal of Economics, scheduled provisionally to appear in the journal at the end of 1998. Johnson's views find support in the writings of Robert Kuttner who argues that the onus is on changes in the functioning of global finance capital rather than domestic
} 
If possible, Murray Sayle is even more resolute in suggesting that Japan will not change, though he is clearly less sanguine about the consequences of stasis. He may however be, as this deservedly extended quotation reveals, more realistic:

With its immense cushion of cash, Japan faces no immediate crisis on the scale of what the 'tiger' economies have suffered. It is the world's top creditor, with external holdings worth close to a trillion dollars. The bank of Japan has $\$ 225$ billion in foreign exchange reserves, nearly twice what then IMF's bailout plan is to cost. Japan's current-account surplus will be $\$ 100$ billion this year, and probably $\$ 150$ billion next year. The United States, which absorbs most of this Niagara of exports, will grumble as usual, but Japan lends it the money to buy Japanese goods, and if Japan ever stopped recycling much of its trade surplus into U.S. Treasury bonds, or sold them to buy gold, the current U.S. bubble would probably collapse too, with interest rates at depression-triggering double digits. A cosmetic cleanup of the Japanese banking system is under way - with the firing of a minister, the arrest of a few unlucky officials for doing what everybody does, the promised use of public funds, and more gestures probably to come........Japanese taxpayers will cover the banks' bad loans, and so the crisis is for the moment under control. There will be no panic layoffs in Japan, no mass unemployment, no revolution - for the time being, anyway. ${ }^{108}$

While less argumentative and more empirically embedded, this type of view finds implicit support in the recent work of Steven Vogel. Vogel claims that even where Japan has implemented changes, the product has been strategic re-regulation rather than deregulation. The implication is that Japan will demonstrate adaptive qualities in this case - but at its own pace. While Vogel's view is not popular, it has one outstanding virtue in that it relies on a wealth of primary data drawn from the telecommunications and financial sectors to support

structures. See, for example, Robert Kuttner, 'What Sank Asia? Money Sloshing Around the World', Businessweek, 27 July 1998.

${ }^{108}$ Murray Sayle, 'The Social Contradictions of Japanese Capitalism' The Atlantic Monthly, June 1998, p.90. 
his contentions. ${ }^{109}$ Few of the prior works cited (by optimists and pessimists) get far beyond a reliance on newspapers (Pempel's work being a notable exception).

Although counterintuitive to the mainstream American view of both optimists and pessimists -- that wholesale reform is required and the major question is whether Japan has the institutional capacity to reform sufficiently - Vogel's work has a depth and focus (on the most important sectors in a globalising economy) that demands it not be prematurely dismissed. Between Johnson's articulate and passionate defence of the virtues of a sustained form of East Asian capitalism, and Vogel's analytic framework and empirical description about what is happening in Japan's most prominent 'globalising' sectors, it is clear that an argument that has been muted to date is emerging to defend the notion of a differential form of capitalist democracy in East Asia that will be both sustained and successful after some phase of turbulence and adaptation.

The mainstream American view dismisses the influence of national culture as a determinant of action. As Alan Greenspan recently suggested in delineating what the Japanese should do in his annual Humphrey-Hawkins Testimony before the U.S. Congress, "First, they need to address their banking situation expeditiously, and in dramatic ways that may even go against the way of the prevailing culture of the way things are done in Japan. And secondly, what they need to do having done that, is to engage in more stimulative fiscal policies, specifically reducing taxes". ${ }^{110}$ Such attitudes do not augur well in view of the assumptions of the revisionists that culture is a firmly entrenched determinant of Japanese policy.

\section{The Japanese Response}

Perhaps nobody understands the contrasting perspectives of the Japanese and Americans, of business and the public sector, better than Glenn Fukushima, former USTR trade negotiation official for the U.S. government and current president of the American Chamber of

\footnotetext{
${ }^{109}$ Vogel, op. cit.

110 Adam Entous, 'Greenspan prods Japan on economy, sees Asia risks', http://biz.yahoo.com/finance/980721/economy_fe_8.html.
} 
Commerce in Japan. Of Japanese ancestry and American birthright, fluent in both languages, and constantly shuffling between the two locales, Fukushima offers a unique analysis in summarising the contrasting perspectives of American and Japanese officials on the prognosis for Japan. While Americans call for greater and more rapid reform, the Japanese he says -- worry about the pace being too fast, the extent too great. The perception of the current state of the economy, he notes, differs dramatically -- with the majority of Japanese simply not sharing the Anglo-American view of a dramatically flawed system on the verge of a meltdown. ${ }^{111}$ Terms such as 'global standards' and 'deregulation' are, Fukushima claims, catchphrases or euphemisms for a vocabulary designed to make Japan more competitive (without, implicitly fundamentally altering the nature of the system).

Fukushima says that the Japanese have studied the British 'big bang' and worry about what they call the 'Wimbledon effect' - the British host this major event on their soil but it is the foreigners who always win! The Japanese are not interested in a deregulation, he concludes, in which the major beneficiaries are foreign firms given unprecedented market access. Recent events in other Asian countries support the contention of a regional fire sale. ${ }^{112}$

Fukushima thus concludes that there is little likelihood of instituting changes simply to satisfy the demands of outside observers. The Japanese believe that American demands will not yield benefits for themselves but that domestic American efforts to push substantial reform in Japan will be side-tracked by five factors. First, will be concerns about the heath of its own economy. As Americans look inwardly on events at home, they will pay less attention to those in Japan. Second, American attention on regional concerns will focus on events in the PRC. President Clinton's visit in late June to Beijing substantiates this view, with his clear stress on human rights, rather than the health of Japan's economy or Japan's or the PRCs regional responsibilities. The third limiting factor is a perennial and axiomatic American concern that pushing the Japanese too far will hurt broader security concerns in North East Asia (particularly in regards to a fragile and vulnerable North Korea). Although the debate on troop withdrawal from Asia, and particularly Japan, has taken on renewed vigour amongst the American policy making community in recent months, a clear consensus

\footnotetext{
${ }^{111}$ For confirmation that this is the mainstream Japanese view see Nicholas D. Kristof, 'Shops Closing, Japan Still Asks 'What Crisis?', New York Times, 21 April 1998 p.A1.

${ }^{112}$ See International Herald Tribune 20-21 June, 1998, p.5.
} 
still exists that the U.S. should sustain a regional policing role. ${ }^{113}$ The fourth limitation is a natural caution that places the US and Japanese position alot closer than many would anticipate - a caution that too rapid, intense and extensive a reform process might actually trigger a meltdown in Japan's economy. Finally, Fukushima suggests, the problems being experienced by the Clinton administration's inability to get Congressional support for IMF funding meant that the U.S. suffered a severe blow to its credibility (especially in the context of the way the U.S. thwarted the development of the aborted Asian Monetary Fund ${ }^{114}$ ). The Congressional failure to support IMF funding has truncated the moral authority of the U.S. in exerting pressure on the Japanese, both within the leadership of the IFIs and among the region's governments whose economies are suffering according to Fukushima.

In summary, Fukushima points to a process of marginal policy adjustment while retaining a focus on traditional values in Japan. The politics of productivity remain intact; it is the welfare of producers rather than consumers that is of primary concern. Market entry will remain limited to what the Japanese public and private sector think of as strategically helpful as the country makes its way through a cyclical downturn rather than a structural crisis. Washington triumphalism is overstated, a sort of wishful thinking by the American media with little foundation as Japan wrestles with yet another adaptive stage that Americans would like to characterise as a crisis. ${ }^{115}$

Fukushima provides us with a widespread (if not unchallenged) context of understanding between the two countries. But comparable to American views, the Japanese perspective can be divided between a far more public and widespread optimistic position (at least in the

\footnotetext{
${ }^{113}$ An exception to this comment in advocating an extensive troop withdrawal was offered by Senator Jeff Bingaman, Ranking Member, Strategic Forces Subcommittee, Senate Arms Services Committee, when he spoke on a panel entitled 'Keeping the Peace: Balancing Security and Economic Issues' on May 6 at the ESI's seventh annual trade conference entitled 'Whither Globalism: A World in Crises?', the Hyatt Regency in Washington DC on 5-6 May 1998.

${ }^{114}$ On the U.S. position on the AMF see Richard Higgott, 'The Asian Economic Crisis: A Study in the Politics of Resentment', New Political Economy, 3 (3) 1998.

${ }^{115}$ These comments were made by Glenn Fukushima on a panel entitled 'Does Japan Need a Miracle?' on May 6 at the ESI's seventh annual trade conference entitled 'Whither Globalism: A World in Crises?', the Hyatt Regency in Washington DC on 5-6 May 1998.
} 
context of the public discourse studied by foreigners) and a more muted, less public pessimistic position generally articulated by political outsiders within Japan.

The Optimistic Scenario. When asked to characterise the Japanese perspective on the current Japanese situation, Michael Zielenziger (who is the Tokyo Bureau chief for Knight Ridder newspapers) suggested that the bureaucrats see no recession and the politicians see no crisis. Rather they see a Japan that saves a lot, is a heavy investor, and is caught in a cyclical downturn that is largely the responsibility of the rest of Asia. While the overexuberant behaviour of the private sector may have contributed to the problem, it was the bureaucracy's role to provide assistance (although he added that many in Japan consider the bureaucracy incapable). ${ }^{116}$ This is the foundation for the optimistic perspective in Japan.

Richard Koo, chief economist at the Nomura Research Institute, probably best reflects and articulates the optimistic Japanese response in a manner consistent with Fukushima's prior comments about Japanese self-perceptions. Koo's view is that, after an extended period, the Japanese are responding in a serious manner to what they consider to be a cyclical crisis. Pushed by Western pressure and the Western experience, the Japanese are developing a widespread system of deposit insurance. The former absence of such a 'safety net' meant that there was no incentive to punish ineffectual banking practices. Fear of exposure, Koo claims, has meant that banks have had to respond by announcing that henceforth they will adopt SEC standards for their accounting practices - a more transparent process. In tandem, such changes will allow the public to recognise the 'good' and the 'bad' banks, and the bad ones will be taken over by the good ones as they fail in an 'orderly' manner. The market mechanism will thus be adapted to work effectively in order to relieve the stress imposed by the credit crunch. Low interest rates give Japan no other option. Americans, Koo firmly suggested, have failed to appreciate Japan's efforts in this regard - and the massive social problems it has generated (including 97 suicides by employees in Tokyo's real estate sector

\footnotetext{
${ }^{116}$ Comments by Michael Zielenziger on a panel entitled 'Does Japan Need a Miracle?' on 6 May at the ESI's seventh annual trade conference entitled 'Whither Globalism: A World in Crises?', the Hyatt Regency in Washington DC on 5-6 May 1998.
} 
in recent years). ${ }^{117}$ The subsequent unveiling of plans by the LDP for a 'bridge bank system' that is designed to wind up failed banks without hurting sound creditors is consistent with the thrust of Koo's comments. ${ }^{118}$ It is not as radical as some Americans might like, but some Japanese believe that it may be more effective in the long term.

If this is the plan of 'orderly change' for the banking sector, what is to happen regarding the role of the bureaucracy, particularly in relation to the issue of economic deregulation? Nobuo Tanaka, the Director of the General Affairs Division of Japan's Ministry of International Trade and Industry, has suggested that his ministry's role is to lead Japan in the process of 'economic restructuring' - a euphemism for deregulation. The current crisis, he suggested in offering a frictional 'edge' to his American audience, was a product of the deflationary impact of the reforms to date. It was MITI who had pushed Japan's Ministry of Finance towards the 'big bang'. But it was the big bang in tandem with too much Japanese investment in the U.S. that accounted for Japan's current problems. While MITI had thus become the object for criticism within Japan, the current problem was a shared, mutual one between Japan and the United States. Tanaka implied that the withdrawal of Japanese investment from the United States was a catastrophic possibility, and bluntly stated that the solution lay in a global arena. The U.S., he suggested, was running away from its commitments to the IFIs in its current hubris generated by the performance of the U.S. economy. ${ }^{119}$

\footnotetext{
${ }^{117}$ These comments were made by Richard Koo on a panel entitled 'Does Japan Need a Miracle?' on 6 May at the ESI's seventh annual trade conference entitled 'Whither Globalism: A World in Crises?', the Hyatt Regency in Washington DC on 5-6 May 1998.

${ }^{118}$ For further details see Yoko Kobayashi, 'Focus - Japan Prepares to unveil Bridge Bank Plan’, 2 July 1998, released by Reuters and available at http:/biz.yahoo.com/.

${ }^{119}$ These comments were made by Nobuo Tanaka, Director, General Affairs Division, Ministry of International Affairs and Industry (MITI), on a panel entitled 'Does Japan Need a Miracle?' on 6 May at the ESI's seventh annual trade conference entitled 'Whither Globalism: A World in Crises?', the Hyatt Regency in Washington DC on 5-6 May 1998.
} 


\section{The Pessimists' position.}

Paradoxically, this may represent the least popular position in Japan because it clusters a peculiar set of assumptions. There may be a popular desire for change in Japan. Those articulating such a view offer two perspectives: First, there are adherents of the optimistic view that Japan can institute (or indeed is already instituting) change that is consistent with American demands for things such as greater financial transparency, accountability, etc.). Whether ingenuous or not, proponents of this view offer the type of articulate view that sounds like the goal is an Anglo-American style model that will be achieved through the 'big bang' deregulation in concert with institutional reforms. ${ }^{120}$ The second group (as shall subsequently be discussed) is composed of the rejectionists. While they think change may be possible, and may indeed occur, they do not believe it will take the form of a 'Western-style' reform. Thus, a small (if growing) residual group exists; advocates of this 'Western-style' reform who openly concede to both an American audience as well as a domestic one that they do not believe that such reform is possible in Japan. This is the group I label the 'pessimists'.

Representatives of such groups within Japan include one element of the opposition parties, notably the Liberal Party. While delivering a speech in Washington DC to a wholly American audience in the Spring of 1998, Yuriko Koike (member of the House of Representatives of Japan's National Diet and of the House's Finance Committee) was very explicit about her party's views.

\footnotetext{
${ }^{120}$ In addition to those already cited in the prior section see comments of Yukihiko Ikeda, Former Foreign Minister of Japan and member of the Liberal Democratic Party, on a panel entitled 'Does Japan Need a Miracle?' on May 6 at the ESI's seventh annual trade conference entitled 'Whither Globalism: A World in Crises?', the Hyatt Regency in Washington DC on 5-6 May 1998.
} 
Koike contended that the liberalisation of the financial sector was proceeding at far too slow a pace and that the Japanese bureaucracy was an impediment to progress rather than an instrument of reform. The realistic prospect for any comprehensive reform was minimal, however, in the absence of a dramatic change in political leadership. Koike implied that the current political leadership drawn from the LDP (then Prime Minister Hashimoto but also extending to the new Prime Minister, Obuchi) had too many vested interests to serve to seriously consider instituting the required changes. ${ }^{121}$

Indeed, elsewhere, Koike has been more emphatic in her comments, referring to the behaviour of the LDP's current and recent leadership as a "political blockade" rather than an instrument of reform. ${ }^{122}$ This is the product, she suggests, of chaos within the governmental leadership, "between the Reformers and the Old Guard, the Elders and the Youth, the $20^{\text {th }}$ Century and the Next, national interests and domestic politics". ${ }^{123}$ Koike's contentions may help explain the choice of Obuchi as successor because he was, by all accounts, the consensual candidate as leader of a series of party factions although neither an inspiring one nor one with a developed programme for radical reform as were his rivals for the post.

With the current prospect of an upcoming election, Koike's comments would not be so alarming were it not for the fact that she thinks as much turmoil exists in the ranks of the opposition parties. With the promise of the accession to office of Morihiro Hosokawa's Japan New Party of the early 1990s now just a distant memory, the opposition parties seem in disarray. Hosokawa himself quit the New Democratic Party three days after it was formed in the Spring of 1998, and with him went (according to Koike) Japan's major prospects for radical reform.

\footnotetext{
${ }^{121}$ Koike's comments were made on a panel entitled 'Does Japan Need a Miracle?' on May 6 at the ESI's seventh annual trade conference entitled 'Whither Globalism: A World in Crises?', the Hyatt Regency in Washington DC on 5-6 May 1998.

${ }^{122}$ See comments issued by Yuriko Koike, 'Titanic Japan: The Iceberg Hits but the Dancing Goes on', 6 May 1998.

${ }^{123}$ Ibid., p.1.
} 
Likening Japan to the Titanic (perhaps a Shakespearean tragedy might have been a better analogy), Koike sees evidence of the inevitable crash. So many opportunities to change course have been missed, so many bad decisions taken; raising taxes in stead of cutting them, increasing medical costs for an ageing population (thus encouraging saving instead of the required spending). Opposition bills introduced to institute reform have been killed completely or reintroduced while devoid of any substantive content. The LDP leadership, she contends, has lost confidence among the populace and is now considered suspect. ${ }^{124}$

The same claim, Koike contends, can be levelled against the bureaucracy. In addition to implementing confused policies, she also accuses them of being disingenuous and, in the case of the Economic Planning Agency under the influence of the Ministry of Finance, of "manipulating information for their own convenience". ${ }^{125}$ The LDP leadership, according to Koike, has abandoned economic leadership to the MOF, ministry officials being in charge of both the Budget Bureau and the Tax Bureau. The financial industry is "regulated not by law so much as the discretion of bureaucrats". ${ }^{126}$ Lacking enough information, and focused on being re-elected, the politicians have abandoned governance to the bureaucrats. Yet "only politicians are capable of radically altering and removing the problems associated to [sic] the bureaucracies.",127

\footnotetext{
124 Ibid., p.3.

125 Ibid., p.4.

126 Ibid., p.9.

${ }^{127}$ Ibid., p.10.
} 
Finally, Japanese industry is not spared Koike's accusations. She contends that Japanese banks have conspired with government bureaucrats, suggesting that such activities reach to the highest echelons of the private sector. Koike claims that "the industry's top representative, Chairman Matsushita of the Sakura Bank, who was the chairman of the Federation of Bankers Association of Japan at the time, balked at opening the books of financial institutions". ${ }^{128}$ Recalling several recent instances of proven undue influencepeddling, Koike contends that bank officials wine and dine their counterparts in the Ministries, with bank resistance to reform institutionally organised around the Federation of Bankers Association of Japan. Koike concludes that "economic reform under the current government is nothing more than a mirage" and that the Japanese banking system is so archaic that it should be exhibited by the Americans in, perhaps, their most notable museum, the Smithsonian Institute. ${ }^{129}$

Koike's claims are extreme and subject to ridicule by many in Japan, from two contrary sides. First, because they may be conceived as understating the degree of convergence that is taking place through the 'big bang' or, alternatively, because Koike advocates reforms that contravene the pattern of policy making that many believe has worked so well for Japan for four decades. Just as clear, however, is the fact Koike echoes a dissatisfaction that is evident among the population - one that found expression in popular support for many of the proposals advocated by the U.S. in the SII talks a decade ago and is growing more intense as Japan's electorate looks for politicians who can offer viable responses to their problems. They don't want to be offered Kioke's explicit message -- that there is no viable solution in the context of the present political structure. That is not a manifesto likely to win mass electoral support.

\footnotetext{
${ }^{128}$ Ibid., p.4.

${ }^{129}$ Ibid., p.5.
} 
The Rejectionist position. The final Japanese response simply rejects the idea of the need for wrenching change in Japan. It has its clearly nationalistic roots in the foundations of the kinds of ideas articulated by Shintaro Ishihara in his book entitled The Japan that can say no: Why Japan will be first among equals, translated and published in English at the end of the 1980s. ${ }^{130}$ At that point, Japanese success was the source of such outspoken pride. Almost a decade later, it is a Japanese refusal to accept too great a foreign influence into the internal workings of the economy that motivates such sentiments.

Contemporary rejectionist responses begin with the basic assumption that the source of the conflict is not predominantly internal mismanagement or the failings of domestic institutions. Rather, it is the influence of external factors, often either explicitly designated as prompted by malign intent or whose motivation remains unspecified.

The source and consequence of such foreign influence are interrelated, focusing on three areas of 'resentment'. The first area of concern is the influence of foreign short-term speculators on the value of the region's currencies. The second area is that of the role of the dollar in exacerbating the region's problems as a denominating currency for trade and loans. The third area of resentment is the heavy increase in direct foreign investment, as Western companies cash in on bargain purchases in markets long inaccessible to them in the aftermath of the region's catastrophic decline. Japan has certainly not suffered the ill effects of any of these elements to the degree endured by some of Asia's smaller economies. Its competitive companies retain their domestic prominence and have been able, for example, to defend their assets at home. But they have been weakened and, as Michael Richardson recently suggested,

Of the three groups of companies - American, Japanese and European - that are most prominent in the struggle, analysts said that the Japanese are now in the underdog position in Asia because of the weakness of their economy,

\footnotetext{
${ }^{130}$ Shintaro Ishihara, The Japan that Can Say No: Why Japan will be First Among Equals (New York: Simon and Schuster, 1989).
} 
banking system and currency. As a result, Japan risks losing its previous commercial dominance in Asia. ${ }^{131}$

While the recent election results that led to Hashimoto's resignation can reasonably be seen as evidence of mass discontent with the LDP's performance. It would be mistake to assume that it is also evidence of a call for the kind of reform demanded by Anglo-American commentators. It might just as well be interpreted as a failure of the LDP leadership to take radical action consistent with more traditional instincts. Radicalism need not mean reform of the kind consistent with Western prescriptions.

Indeed, rejectionist views are not only the province of the kind of extremists often seen bellowing through bullhorns on the streets of Tokyo by Western visitors. Rejectionist impulses are evident in the suggestions of senior economic and political figures. For example, in stressing the role of Western speculators in promoting Japan's problems, Yoh Kurosawa, Chairman of the Industrial Bank of Japan, recently suggested in the Nikkei Weekly that

Asia's economic crisis was triggered by a series of monetary crises caused in part by various internal problems but more directly by the massive influx of foreign currency to the region, which snowballed out of all proportion to the size of those economies. Another important cause was also external: After praising Asian economies to the skies as the growth centre for the world economy, foreign short-term money quickly pulled out as soon as it sensed possible overheating....... The developed countries are also to blame for demanding deregulation of Asian financial markets before they were ready. $^{132}$

\footnotetext{
${ }^{131}$ Michael Richardson, 'West Snaps up Asian Businesses', International Herald Tribune, $20-21$ June p.5. ${ }^{132}$ Yoh Kurosawa, 'Reflections on Asia's Crisis, Japan's Role', The Nikkei Weekly, 25 May 1998, p.22.
} 
Here the tendency towards focusing blame on foreign speculators by a senior banking official in the popular press is quite transparent - and echoes the sentiments expressed throughout Asia - that Western countries have used this opportunity to derail the Asian economic miracle. But rather than support the development of an Asian monetary fund designed to limit future currency turmoil, Americans prefer to support the IMF in its efforts to reform Asia's economies. ${ }^{133}$

As previously mentioned, a second area of focus by rejectionists is that of the role of the dollar in provoking the current crisis. One consequence of the belief that dollar dependency and foreign currency speculation is at the heart of Asia's (including Japan's) current problems is a far-reaching domestic discussion about the viability of establishing a regional currency. One of the authors of an ongoing research project, conducted by the Bank of Tokyo's affiliated Institute for International Monetary Affairs and the Thailand Development Research Institute, suggested that a repetition of an East Asian financial crisis could potentially be avoided by taking strident measures to reduce the region's dollar dependency. The policy solutions being advocated by the group include a proposed "agreement not to use the U.S. dollar for settlements within the region, but to use an index of local currencies or a single currency". The dollar would only be used for external transactions. ${ }^{134}$

\footnotetext{
${ }^{133}$ For a discussion of the U.S. rejection of the AMF and a defence of institution see Yoshihiro Fujii, 'European Example Provides Boost to Backers of Single Currency for Asia', The Nikkei Weekly, 25 May 1998, p.23.

${ }^{134}$ Doungsuda Fungladda, 'Study Aims for Asian Currency', The Nikkei Weekly, 23 March, 1998, p.23.
} 
As Yoshihiro Fujii elsewhere suggests, American refusal to countenance the setting up of an AMF in 1997 may have been motivated by "concerns that creating a monetary fund in Asia could possibly lead to the creation of a yen zone, which would primarily serve the interests of Japan". Interestingly, Fujii subsequently fully concedes that "an Asian monetary fund could serve as a tool to realise an Asian-style common currency" but contends that its primary purpose is to establish itself as a "lender of last resort". While one pragmatic solution, the resistant underpinnings to both the influence of speculators and the dollar in favour of Asian independence are evident. Fujji states that "If Asian countries could devise a mechanism to counter speculative currency trading, they would be able to create an environment that would allow each country to rebuild its economy on its own". ${ }^{135}$

Foreign direct investment is the third area of concern for rejectionists when focusing on external influence. American investors note that many Asian countries have long denied them entry to their markets, but now these investors have opportunities not only to do so, but do so at a fraction of their former cost. "Countries hit hardest by the crisis, including Thailand, Indonesia, South Korea, Malaysia, and the Philippines, are relaxing restrictions on foreign ownership in areas including financial services, property and retailing where outsiders were previously barred or tightly controlled."136

Such possibilities recently prompted Mathathir bin Mohamad to warn "of attempts by foreign robbers to take over Malaysian companies". The fear he expressed was the countries of East Asia risked becoming a set of Latin American-style 'banana republics' with little economic or political independence in a thinly-veiled reference to the motivations of American investors. ${ }^{137}$ Mahathir, in his most belligerent posture, however warned

That the people will show their resentment against those outsiders who will lord it over them once again. Bitter over the take-over of their nationalist corporations they will show their feelings in many ways. Sooner rather than later they will think of regaining control over their economies. They will

\footnotetext{
${ }^{135}$ All quotations are taken from Yoshihiro Fujii, 'European Example Provides Boost to Backers of Single Currency for Asia', op.cit.

${ }^{136}$ Michael Richardson, 'West Snaps up Asian Businesses', op.cit.
} 
regard this as a new war of liberation. Even if they want to avoid violence, violence must come as the new capitalists disregard the signs........the new capitalists would not want to miss the opportunity to dominate the world and make lots of money in the process.... Only if their countries restrain them will the future of the world of which Asia is a part be peaceful and prosperous. $^{138}$

Of course, these are the views of a noted Malaysian nationalist, not a Japanese national, and should be considered with that in mind. Yet, if adjudged as potentially irresponsible, that does not detract from their power to either persuade or reflect the degree of discontent currently felt towards developing and potential Anglo-American FDI in Asia.

Japan has historically employed sophisticated means to limit inward foreign direct investment (IFDI). ${ }^{139}$ Simultaneously, it has grown to be among the largest outward direct investors (FDIA) - in both Asia and globally - with a ratio of about 20 to $1 .{ }^{140}$ Yet, while the Asian financial crisis poses a threat to the secure position of Japanese firms both at home and in Asia, it is interesting that anecdotal evidence supports the proposition that little challenges the traditional perspective of Japan's economic leadership on how things should operate in this domain. Tadahiro Sekimoto, chairman of the NEC corporation, for example, recently argued that "Japanese-style management needs to become more flexible, quick and dynamic while keeping its core values", ${ }^{141}$ while many Japanese corporate leaders reflect the traditional belief that IFDI should take the form of minority foreign shareholding in joint stock companies.

\footnotetext{
137 Ibid.

${ }^{138}$ Quoted in article by Oon Yeoh, 'Asian Leaders Dissect what hit the region', The Nikkei Weekly, 8 June 1998, p.1.

${ }^{139}$ For detailed discussions of constraints on inward FDI see Paul Doremus, William Keller, Louis Pauly and Simon Reich, The Myth of the Global Corporation (Princeton, NJ: Princeton University Press, 1998); Louis W. Pauly and Simon Reich, 'National Structures and Multinational Corporate Behavior: Enduring Differences in a Globalizing World, International Organization, Winter 1997, pp.1-30; Simon Reich, "'Manufacturing' Investments? National Variations in the Contribution of Foreign Direct Investors to the U.S. Manufacturing Base in the 1990s", Review of Political Economy, Vol. 3, No. 1, 1996.
} 
Nikko Securities recent agreement with Travelers to form a new company in Japan reflects that view, with Travelers, despite the unprecedented size of the deal, being the minority partner. What did the Masashi Kaneko, president of Nikko Securities think of the arrangement? Well he responded with an interesting traditional line when examining a new problem when he suggested that "The problem we face is globalisation. Companies can no longer satisfy customers by themselves, without a global partnership". ${ }^{142}$ Globalisation was not here depicted as requiring a revolutionary response but, rather, reluctantly accepting the need for a traditional one familiar to Japanese companies though rarely employed in Japan. For Nikko, one of the largest companies in one of the most sophisticated and technologically-advanced sectors in the world, the concept of globalisation means little more than a joint venture. ${ }^{143}$ Other Japanese companies in the financial sector have responded in a very traditional way - by forming strategic alliances with suitable partners to protect themselves against foreign competitors.

In sum, the rejectionists recognise that Japan is faced with an enormous set of problems that focused on the need for domestic reform and to provide external leadership. They are often less than sanguine about Japan's capacity to do either. But they are more assured in believing that Asia in general, and Japan in particular, will have severe problems if attempts are made to reconcile an Anglo-American form of capitalist democracy with the varied forms of indigenous Asian cultures.

\section{Conclusion}

\footnotetext{
140 Davis B. Bobrow, Steve Chan and Simon Reich, "Southeast Asian Prospects and Realities: American Hopes and Fears", Pacific Review, Vol. 8, No.4, Winter 1995.

${ }^{141}$ Quoted in Masako Fuduka, 'Forecasts for Asia range from rosy to bleak', The Nikkei Weekly, 8 June 1998, p.2.

${ }_{142}$ Quoted in Makoto Sato, 'Financial Realignment Picks up Speed', The Nikkei Weekly, 8 June 1998, p.1.

${ }^{143}$ For a discussion of the terms under which U.S. companies entered Japan in the 1960s see Dennis J. Encarnation and Mark Mason, "Neither MITI nor America: The Political Economy of Capital Liberalization in Japan." International Organization, 44, 1 (Winter 1990), pp.25-54. For a general discussion of the contrasting ways in which American firms invest in Japan and Japanese firms invest in the U.S. see Dennis J. Encarnation, Rivals Beyond Trade: America Versus Japan in Global Competition (Ithaca, NY: Cornell, 1992).
} 
The ideology of neo-liberalism has certainly become predominant in the language of nongovernmental institutions at the end of the Millennium. It includes an emphasis on markets as structures of authority with a corresponding constraint in the role of the state. Deregulation, liberalisation and privatisation predominate as policy initiatives, and diplomatic initiatives stress the importance of IGOs, NGOs and IFIs in decision making at both the regional and multilateral level. Bilateral policy co-ordination, using instruments that don't primarily involve market mechanisms, is certainly out of vogue.

Whether initiated by the United States or not, elements of the neo-liberal agenda have been met with approval in Washington and certainly influence both the style and substance of current American policy making. When further integrated with an element of American triumphalism, however, this mix becomes a powerful and incendiary force. Such triumphalism is often smug in tone, simplistic in its approach to policy, and risks both generating resentment abroad and potentially fatally flawed policy (in terms of American interests and global stability).

Nowhere is this capacity to shape the agenda and influence the pattern of global development more evident that American policy in Asia. Both Asia's broader financial crisis and Japan's narrower economic problems have bred the same response from American policy makers; that this is an opportunity to consolidate a convergence towards a more harmonised, homogenised form of global capitalism. 
There are inherent risks in such an approach. It assumes both a willingness and a capacity of foreign governments and civil society to discard generations of culturally-embedded attitudes and corresponding institutional structures in favour of an Anglo-American model that they have historically considered suspect. Accusations that their indigenous form of capitalism is corrupt and that their democratic institutions have been stymied may even contain elements of truth. Stylistically, however, brazen and public accusations of this type are unlikely to generate mass support for an emphatic and radical shift to a comparable form of liberal capitalism found in the West. The Soviet bloc was notable for the lack of political legitimacy of its regimes; for the failure of its economic institutions to generate wealth; and for the flagrant way in which the egalitarian posture of its ideology was violated by elites. Asia has not suffered to the same degree or in the same way from these failings. Any generalisation is inherently flawed as one surveys the terrain of East Asia or even the countries currently in crisis. But, despite the evident economic failings of Indonesia or the Philippines, the region's national economic institutions have been very successful in generating wealth from Korea to Hong Kong, from Malaysia to Singapore. The tendency throughout the region has been towards a more egalitarian distribution of wealth than commonly found in the West (despite the nepotistic excesses of Suharto) and democratic institutions have extended - albeit at a pedestrian pace. With few exceptions, regimes have therefore proven to be legitimate. Where they have not been, they have been replaced (as in the Philippines).

Any assessment of Japan's post-war record is consistent with these generalisations. Having generated unprecedented wealth and a stable democracy since 1945, the Japanese have been inclined to forgive the excesses of its economic and political leadership. The same is true of an American public that has steadfastly maintained in opinion polls that it has little interest in President Clinton's historic land dealings or personal promiscuity as long as the economy performs well. Japan's bureaucracy may be in retreat and its political leadership in disarray to the dissatisfaction of the Japanese public. Indeed, public frustration may become amplified beyond its traditional fairly muted volume. But there is a big difference between the public being dissatisfied with the current performance of the Japanese economy and a desire for radical, Anglo-American style reform. Little evidence of the latter exists and, in that context, persistent American efforts to push such policy initiatives is only likely to breed resentment, even if they are instituted on a limited basis. 
Japan has become, in many regards, the test case for American resolve to push towards a process of convergence of economic and political institutions in Asia. Japan has been regarded by many as a model for regional development and, as the region's largest economy, is the thin end of the wedge towards a radical redefinition of the relationship between polity and economy in Asia. The potential reform would move the region's civil society away from Confucianism and the politics of productivity towards liberalism and the politics of consumption.

Such reforms, however, also stress the invigoration of multilateral and regional forums as instruments of the harmonisation of standards, of markets as primary mechanisms of transaction and distribution, and of non-governmental bodies as sources of policy initiatives. This thrust, however, sacrifices a more traditional bilateral approach to policy co-ordination.

In this context, the strategy, style and substance of American policy towards Japan, and its potentially potent failings, become clear. Robert Rubin, the alternatively despised and vaunted U.S. Treasury Secretary, has publicly stated that the policies of governments - and not just the activities of markets - have become interdependent in a new globalised economy. Japan, he suggested emphatically in a recent interview, "holds the key to the resolution of Asia's and indeed much of the world's financial problems". Yet the extent of policy co-ordination between the two governments was a quid pro quo of U.S. currency market support for the yen in exchange for some publicly unspecified Japanese government reforms in its banking sector. Whatever deal was struck was with Hashimoto, and presumably contingent on his retention of office. The period that Rubin depicts as a window of opportunity for action is closing, and he predicts that the failure to do so will result in severe market reactions against Japan. ${ }^{144} \mathrm{~A}$ recent decision by Moody's to initiate a review of Japan's credit rating with a view to downgrading their precious Aaa rating is just the tip of this particular iceberg. ${ }^{145}$

\footnotetext{
${ }^{144}$ All these comments are taken from an interview with Robert Rubin by Gerard Baker in an article entitled 'US Eyes the Asian Storm', Financial Times, 13 July 1998, p.19.
} 
The U.S. agenda of establishing sweeping banking reform, stabilising the yen's value, and maintaining the value of the PRC's renminbi is ambitious, especially while Rubin denies Asian accusations of dogmatism and promulgates the claim that the U.S. is being pragmatic and characterises the IMF's policies as responsible and benign. Yet Rubin's policy onus remains unshakeable; the answer to the problem is structural and macroeconomic reform coupled with higher interest rates to avoid further currency depreciation. ${ }^{146}$

All the focus in Rubin's prescription therefore remains on Japanese domestic reform (so that their banking system conforms to Anglo-American standards) and the use of markets as governance structures. Consistent with the distinction drawn in the earlier sections of this paper, harmonisation and market mechanisms are the instruments of American foreign policy. Rubin may defend the American position as pragmatic in assisting Japan (and Asia) in escaping from its present quagmire. But this response is also consistent with the current messianic thrust of American foreign policy because such policies, if instituted, ensure a movement towards convergence (or capitulation, depending on whatever position is adopted).

The analysis of the varied dominant positions in each country suggests three main points. First, the current thrust of American policy relies largely on Japanese accommodation and adjustment to external pressure rather than effective joint action to address an abiding problem in which both countries are entwined. Japan is not like the other Asian countries caught up in the varied financial crises to date. American markets can probably tolerate the enlarged exports and reduced imports that it is currently experiencing from the rest of Asia. Despite the fact that the American trade deficit has predictably grown, the net effect of these imports may well usefully serve to dampen inflation.

\footnotetext{
145 See Andrew Morse, 'FOCUS-Moody's jolts Japan ahead of leadership vote', 23 July 1998, http://biz.yahoo.com/finance/980723/japan_rati_3.html.

${ }^{146}$ Rubin interviewed by Baker, op. cit.
} 
Japan represents a whole series of problems that are, potentially, of a different variety and certainly of a different magnitude to the rest of Asia - and could cause severe damage to the American economy in a form and to a degree that the others could not. Although the U.S. deficit with Japan has grown, an American market flooded with Japanese goods could so enlarge the U.S. trade deficit that it could have an adverse effect on U.S. interest rates. And it is the Japanese who, in recycling their dollar surpluses through the purchase of U.S. Treasury bonds, keep the deficit viable. It doesn't take much acumen to recognise that the growth of the financial crisis in Japan -- to the point where Japanese investors would have to sell either their portfolio or direct investment assets -- could have a damaging effect on both employment and interest rates in the U.S. In this situation the Treasury might have to raise rates to attract other investors to replace Japanese withdrawals while Japanese-owned plants might close as they withdrew funds from North America. A 'loveless embrace' it may be, but it is one where both sides risk inflicting tremendous damage if one defects on too grand a scale.

Second, the main onus of the Japanese policy community rhetorically concedes that the country must reform. But there seems to be little political will to pursue the tripartite policies advocated by the United States of "transparency; strengthening national financial systems; and ensuring private actors bear more responsibility for their decisions". ${ }^{147}$ While the need for banking reform is widely recognised, for example, the process advocated in Japan of a 'bridge plan' lacks any of the 'short, sharp shock' element of treatment advocated by American policy makers. Banks will be folded one into another as the strong envelope the weak in a traditional Japanese style, what Murray Sayle earlier referred to as 'ethno-economics'.

${ }^{147}$ This is characterised as Robert Rubin's agenda in 'Strengthening Global Finance', Financial Times, 16 April 1998. 
Japan may want to address its problems at dig itself up from being buried under a growing heap but the welter of sentiment avidly resists the adoption of an Anglo-American style of capitalism. Few in a position of influence in Japan believe that the country can or should converge with Western standards. The opposition politicians who advocate such an approach are politically too weak to pursue such an agenda successfully. Japan must adjust, they insist, but as many cited in this paper (from varied perspectives on both the American and Japanese sides) make clear, it will be done in a Japanese-style way. American attempts to get Japan to institute radical financial reform and let the markets sweep away the debris may well backfire, leading to greater resentment and resistance rather than acquiescence to U.S. demands. ${ }^{148}$

From this perspective, despite the encouraging rhetoric from Japan about reforms, and from President Bill Clinton about those proposals, there is no sign of drastic reform on the horizon. Japan is too steeped in a tradition that constrains markets and a culture that is mutually supportive to abandon society to the exigencies of the international economy.

The third point is that no institutional structure for policy co-ordination currently exists that is founded on the alternative perspective of 'comparative capitalism' (and thus mutual recognition) currently out of fashion among American policy makers. Acceptance of mutual recognition would allow for authoritative and flexible bilateral institutions for policy coordination. The rejection of a policy of mutual recognition has dictated that there is no current mechanism for arbitrating the differences through negotiated compromise that still clearly exist across the two economies.

\footnotetext{
${ }^{148}$ For an example of such resentment in the context of U.S. demands related to the attempt to stabilise the falling value of the yen see Alex Brummer, 'Japan Bows to US Pressure: Officials Resent Yen Rescue Terms', The Guardian, 19 June 1998, p.23.
} 
Furthermore, current regional and multilateral institutional mechanisms are ill suited for the task of policy co-ordination across the Japanese and American systems. The IMF has little credibility in the region, distrusted because it is seen as pushing a neo-liberal agenda. It is thus considered more an instrument designed to impose radical change on the Asian countries than a means of detailed compromise. APEC, despite its breadth, might under specific conditions have evolved into a mechanism for achieving bilateral co-operation and co-ordination in the region. But the great resentment towards the U.S., indicated by the kind of comments quoted earlier from Mahathir, suggests that such a possibility is now moribund. No other suitable pan-Asian institution exists for the resolution of the type of policy problems between the U.S. and Japan that have been outlined, while the two countries have no ongoing forum for deliberating over such policy issues.

In essence, there is no existing mechanism to co-ordinate policy should the American focus shift from an evangelical stance to an acceptance that the two systems will not converge but must co-exist. If the two sets of policy leaders decide that there is a need for a deliberative body - bilateral, regional or multilateral - then none are readily available for adoption. There is an evident vacuum should the situation worsen and the U.S. abandon its current strategy of relying on markets, IFIs and a process of convergence.

The implications of these three points, if accurate, are potentially dramatic. The only viable solution appears to be some form of policy co-ordination between the two countries. Yet the prospects of this look pretty bleak, with American policy makers focusing on market structures and only offering interventionist activities that conform to market mechanisms (like buying yen to sustain its value against the dollar). Japanese decision-makers, in contrast, seek solutions that avoid the governance of market structures and with it the evident pain it will inflict on those most highly invested in the present system. Finally, if and when the current breakdown does occur, there will be no institutional apparatus to co-ordinate a recovery. 
The hug between the two countries is becoming increasingly forlorn, if not a source in itself of friction, as the United States pushes an agenda of reform and Japan coyly evades American demands as it speaks the language of change. To recall Murray Sayle's comment, it is a 'loveless embrace' and, like a sumo wrestler's hug, it is an increasingly constricting one for the Japanese and the Southeast Asians.

http://www.msnbc.com/news/173807.asp

In that context, the key questions to be addressed in this paper are:

1) What are the different perspectives on Japan's prospects and, relatedly, the assumptions upon which the contrasting Anglo-American

and East Asian perspectives of the viability of Japan's economy rest?

2) How representative is Japan of East Asia's broader economy?

3) Who opposes the American perspective and what are the ways and locations for this opposition?

4) What are the theoretical implications and policy consequences of any sustained differences in terms of the viability of the hegemony of the American model of capitalism and democracy in the region? 